\title{
The role of the audit committee in their oversight of whistle-blowing
}

\author{
Gladys Lee \\ The University of Melbourne \\ Neil Fargher \\ The Australian National University
}

Summary: We examine the role of the audit committee in their oversight of whistle-blowing. Our study examines whether the quality of the audit committee, captured by its independence, expertise, and diligence, is associated with two whistle-blowing outcomes: the choice of reporting channel (external whistle-blowing versus internal reporting) and the likelihood of retaliation against the whistle-blower. Using a sample of internal and external whistle-blowing cases, we find that a high-quality audit committee reduces the probability that misconduct is reported externally relative to internally, and reduces the probability that a whistle-blower experiences retaliation. We further find that a higher quality audit committee is associated with the implementation of a stronger internal whistle-blowing system, which in turn reduces the likelihood of external relative to internal reporting. Together, our findings suggest that a high-quality audit committee helps to ensure that whistle-blowing disclosures are received and resolved through internal channels.

Keywords: Audit Committee; Financial misconduct; Fraud; Whistle-blowing

* We gratefully acknowledge comments from Gary Monroe, the two anonymous reviewers, Greg Shailer, Mark Wilson, Juliana Ng, Sigi Goode, Michael Davern, Jonathan Jona, Xinning Xiao, participants at the Australian National University and the University of Melbourne presentations and participants at the AFAANZ 2015 Conference. We also thank Isabel Wang for research assistance.

Corresponding author: Gladys Lee, gladys.lee@unimelb.edu.au. Department of Accounting, The University of Melbourne. 198 Berkeley Street. Melbourne. VIC 3000. 


\section{INTRODUCTION}

Whistle-blowing is an important mechanism that helps to prevent fraud (Hooks, Kaplan, and Schultz 1994), detect fraud (Dyck, Morse, and Zingales 2010), and improve shareholder protection (Baloria, Marquardt, and Wiedman 2016). Our study extends prior literature by examining whether a key corporate governance mechanism—-the audit committee—plays a role in providing oversight of whistle-blowing. Specifically, we ask two related questions: (1) Does a high-quality audit committee encourage internal reporting relative to external whistle-blowing? (2) Does a high-quality audit committee affect the likelihood of retaliation against the whistle-blower?

We are interested in the role of the audit committee because good practice guidance suggests that companies should instigate whistle-blower arrangements with reporting lines to the audit committee (ASIC 2016), the audit committee primarily sets the tone of the internal control environment (Turley and Zaman 2007), and the audit committee is most commonly the recipient of internal reports involving fraud (Kaplan and Schultz 2006). Thus, we expect the quality of the audit committee to affect the likelihood of whistle-blowing reporting and retaliation.

Audit committee members are charged with providing oversight of financial reporting matters and bear significant reputational costs for financial reporting failures (Srinivasan 2005). Research has found that audit committee members act in a self-serving manner at times (Bierstaker, Cohen, DeZoort, and Hermanson 2012; Keune and Johnstone 2015). Given the potential for significant reputational penalties when fraud is revealed, it is possible that audit committee members may act in a self-serving manner and "hide" internal reports of misconduct, thereby leading to external whistle-blowing. However, this problem might be mitigated when the audit committee is of a high quality. A high-quality audit committee is conventionally defined in terms of independence, expertise, and diligence (Beasley, Carcello, Hermanson, and Neal 2009; Bédard and Gendron 2010; Fiolleau, Hoang, Jamal, and Sunder 2013; Gendron and Bédard 2006). A high-quality audit committee has been found to be more independent, objective and less susceptible to management influences (Karamanou and Vafeas 2005; Li, Mangena, and Pike 2012; Spira 1999). By providing strong oversight of the internal control environment, a high-quality audit committee is potentially more effective at resolving issues internally, in turn reducing the likelihood of external whistle-blowing and whistle-blowing retaliation. Therefore, 
we expect firms with audit committees of higher quality to have a lower likelihood of external whistleblowing relative to internal reporting. ${ }^{1}$ However, given that the effect of the audit committee on external whistle-blowing is ex-ante unclear, we investigate the effect of audit committee quality on the likelihood of external whistle-blowing relative to internal reporting.

We also examine a second aspect of having an audit committee of high quality. A significant cost of whistle-blowing is the risk of retaliation, which is typically defined as undertaking an undesirable action against a whistle-blower who reported wrongdoing internally or externally (Near and Miceli 2008; Rehg et al. 2008). Because the audit committee plays a significant role in setting the tone of the internal control environment, we examine whether the likelihood that a whistle-blower experiences retaliation for reporting misconduct, to the extent it can be externally observed, is reduced when there is an audit committee of higher quality.

Our study is related to, but differs from, prior work on whistle-blowing in several aspects. Studies on whistle-blowing often employ experiments and surveys (Miceli, Near, and Dworkin 2008). A limitation of these studies is that they often capture whistle-blowing intentions, which often do not translate to actual whistle-blowing behavior (Mesmer-Magnus and Viswesvaran 2005). We focus on actual whistle-blowing behavior by adopting the archival approach employed by Bowen et al. (2010), and construct our sample by gathering actual cases of financial allegations from press reports. We identify incidences of financial allegations where the whistle-blower reported to an external party such as to the media, parliamentary members, and authorities (i.e., external whistle-blowing cases). We benchmark our external whistle-blowing cases to cases where misconduct was reported internally to a party within the organization and not publicly reported by the whistle-blower. Internal reporting cases are generally difficult to observe. We identify a sample of internal reporting cases that have been publicly revealed through press reports, court transcripts, and corporate disclosures. This provides a

\footnotetext{
${ }^{1}$ The terms "internal whistle-blowing" and "internal reporting" are often used interchangeably in the literature (e.g. Kaplan, Pope, and Samuels 2011; Miceli and Near 2005; Seifert, Sweeney, Joireman, and Thornton 2010). Some scholars restrict whistle-blowing to encompass only non-obligatory disclosures (Donkin, Smith, and Brown 2008; Jubb 1999). It is difficult in our sample to adequately separate obligatory and non-obligatory disclosures; hence, we use the broader term "internal reporting”.
} 
unique opportunity to compare characteristics of firms with external whistle-blowing incidents to a control group of internal whistle-blowing cases. ${ }^{2}$

We use a sample from the Australian setting and choose this sample for two reasons. First, compared with the U.S. or the U.K., Australia has less comprehensive corporate whistle-blowing legislation (Wolfe, Worth, Dreyfus, and Brown 2014). ${ }^{3}$ When whistle-blowing legislation is weaker, corporate governance is more important (Klapper and Love 2004). Thus, the audit committee, as one key corporate governance mechanism, arguably has a more important role in providing oversight of whistle-blowing in Australia. Second, the U.S. has developed a whistle-blowing program that provides financial incentives to blow the whistle (e.g., the Dodd-Frank Act 2010), while Australia does not provide such a program. In a setting without strong financial incentives for whistle-blowing, there is less concern that our results are driven by the potential confounding factor that external whistle-blowing is affected by financial incentives.

We expect a high-quality audit committee to provide greater oversight of whistle-blowing. We capture audit committee quality using a composite measure based upon a factor analysis of audit committee independence, expertise, and number of audit committee meetings (Beasley et al. 2009; Bédard and Gendron 2010; Fiolleau et al. 2013; Gendron and Bédard 2006); we also consider separate components of audit committee quality in our analyses. Consistent with our expectations, our results indicate that firms with a high-quality audit committee are associated with a lower probability of experiencing external whistle-blowing in comparison with internal reporting and a lower probability that a whistle-blower experiences retaliation. We further examine and find that a high-quality audit committee is associated with the implementation of a stronger internal reporting system (as captured by observable aspects of a reporting system, such as provision of a reporting hotline, ability to report anonymously, having a designated whistle-blowing officer, and providing protection to whistle-

\footnotetext{
${ }^{2}$ A limitation of our approach is that we cannot identify cases where no reporting occurred or cases reported internally that were not subsequently revealed publicly. In using press reports to identify incidences of internal reporting, our sample is likely biased toward larger and more controversial cases. This bias is likely to work against finding differences between internal and external reports.

${ }^{3}$ For example, only two of six states in Australia offer state-level whistleblowing protection to private sector employees, and limited protection is available to those who provide information to governmental agencies, such as the Australian Competition and Consumer Commission and the Australian Competition Tribunal (Smith 2008).
} 
blowers). Further, a path analysis provides evidence that a higher quality audit committee is associated with the implementation of a stronger internal reporting system and a lower likelihood of retaliation; these two factors, in turn, reduce the likelihood of external compared with internal whistle-blowing. Together, our findings indicate that a high-quality audit committee provides better oversight over whistle-blowing by ensuring that a good internal reporting system is in place, internal reports are adequately resolved, and whistle-blowers are protected against retaliation.

Our study makes the following contributions to the literature. First, we contribute to the literature that examines firm-level predictors of whistle-blowing (Bowen et al. 2010). Prior studies have documented that an organizational environment that is supportive of whistle-blowing helps to facilitate internal whistle-blowing and reduce external whistle-blowing (Cassematis and Wortley 2013; Keenan 2000; Miceli and Near 1984). We extend this body of literature by providing evidence that a highquality audit committee is one key corporate governance mechanism that helps to foster an environment conducive to whistle-blowing.

Second, we contribute to the literature on whistle-blowing retaliation. Studies have explained retaliation from the perspective of the power of the whistle-blower or wrongdoer (Lee, Heilmann, and Near 2004; Rehg et al. 2008). We add to this literature by finding that better audit committee quality is associated with a reduced likelihood of whistle-blowing retaliation, suggesting that corporate governance helps to explain whistle-blowing retaliation. This finding is also important to practitioners because retaliation lawsuits are costly and time-consuming to both the firm and the whistle-blower (Daniel 2003).

Third, we contribute to the stream of research on internal whistle-blowing systems by documenting that a higher quality audit committee is associated with the implementation of a stronger reporting system. Prior studies have examined the cost and benefits of a strong internal whistle-blowing system (Brennan and Kelly 2007; Lee and Fargher 2013; Pittroff 2014). We provide further evidence that having a high-quality audit committee contributes to establishing a strong internal reporting system.

Fourth, we contribute to the literature on audit committee effectiveness. Research on the audit committee's role in overseeing the whistle-blowing process is still in its infancy (Carcello, Hermanson, and Ye 2011). Studies have shown that audit committee members lose objectivity and act in a self- 
serving manner that is consistent with their personal incentives (Bierstaker et al. 2012; Keune and Johnstone 2015). While it is possible that audit committee members "hide” internal whistle-blowing disclosures because the revelation of a fraud leads to penalties (Fich and Shivdasani 2007; Srinivasan 2005), we do not find such evidence in our study. Our results are consistent with prior research that found a higher quality audit committee improves oversight of the internal control environment (Goh 2009; Klein 2002; Xie, Davidson III, and DaDalt 2003).

\section{RELATED LITERATURE ON WHISTLE-BLOWING}

Whistle-blowing is defined as disclosing questionable practices involving an organization or its members internally or externally (Chiasson, Johnson, and Byington 1995). Whistle-blowing research has examined whether whistle-blowing is affected by personal characteristics of the whistle-blower, such as socio-demographics (Cassematis and Wortley 2013; Rothschild and Miethe 1999), personality traits (Bjørkelo, Einarsen, and Matthiesen 2010; Park, Blenkinsopp, and Park 2014), and value orientation (Ayers and Kaplan 2005; Park et al. 2014; Park, Rehg, and Lee 2005). Other studies have examined the effects of characteristics of misconduct, such as severity (Callahan and Dworkin 1994; Schultz, Johnson, Morris, and Dyrnes 1993) or frequency (Douhou, Magnus, and Van Soest 2012; Lee et al. 2004; Miceli and Near 1985); characteristics of the wrongdoer, such as the power (Gao, Greenberg, and Wong 2015; Skivenes and Trygstad 2010) or relational closeness to the wrongdoer (King 1997; Waytz, Dungan, and Young 2013); and the use of financial rewards for whistle-blowing (Andon, Free, Jidin, Monroe, and Turner 2016; Brink, Lowe, and Victoravich 2013; Stikeleather 2016).

One stream of research considers whether the organizational environment affects whistleblowing. The theoretical premise is that pro-social organizational behavior such as whistle-blowing involves a cost-benefit analysis (Miceli et al. 2008). When the organization is supportive toward whistle-blowing, whistle-blowing is less costly and individuals are more willing to report misconduct. For example, individuals are more likely to blow the whistle internally when there is greater organizational and co-worker support and approval for whistle-blowing (Cassematis and Wortley 2013; Keenan 2000; Miceli and Near 1984), greater organizational responsiveness to whistle-blowing reports (Barnett, Cochran, and Taylor 1993), and greater trust that the whistle-blowing allegation will be 
investigated (Curtis and Taylor 2009). Individuals are also more likely to report internally when they perceive fairness in their interactions with management regarding issues relating to whistle-blowing (Seifert et al. 2010; Soni, Maroun, and Padia 2015). Conversely, individuals are more likely to report externally when whistle-blowers perceive that an initial or previous whistle-blowing report received an ineffective response (Callahan and Dworkin 1994; Zhang, Pany, and Reckers 2013).

While these findings highlight the importance of having an organizational environment that is supportive of whistle-blowing, research has yet to examine specific corporate governance mechanisms that foster such an environment. Research has identified a range of key corporate governance mechanisms that promote ethical behavior, including greater board independence (Beasley 1996; Dechow, Sloan, and Sweeney 1996; Sharma 2004; Uzun, Szewczyk, and Varma 2004), number of board meetings (Hou and Moore 2012), absence of CEO serving as the chairperson of the board (Dechow et al. 1996; Sharma 2004), smaller board size (Beasley 1996), and greater audit committee independence (Abbott, Park, and Parker 2000; Beasley 1996). We extend prior research to examine the effect of the audit committee as a key corporate governance mechanism on the whistle-blowing process. We have chosen to examine the effect of the audit committee on the whistle-blowing process because regulators and professional best practice guidelines recommend that audit committees foster and encourage whistle-blowing (ASIC 2016; PwC 2011), and the audit committee is the most common recipient of internal whistle-blowing reports involving fraud (Kaplan and Schultz 2006).

\section{HYPOTHESIS DEVELOPMENT}

\section{Audit Committee and External Whistle-blowing}

Individuals who choose to report misconduct can report misconduct internally to management or externally to parties outside the organization. Internal reporting is advantageous to management because it provides an opportunity to correct the misconduct in a timely manner (Barnett et al. 1993; Berry 2004). Conversely, external whistle-blowing is more costly to the organization and tends to occur when internal reporting has been ineffective (Miceli et al. 2008). Therefore, we examine the likelihood of external whistle-blowing compared with internal reporting. 
We expect the audit committee to play an important role in providing oversight over whistleblowing because the audit committee sets the tone for the internal control environment (Turley and Zaman 2007) and is most commonly the recipient of internal whistle-blowing reports involving fraud (Kaplan and Schultz 2006). Research suggests that an audit committee of higher quality is more independent, objective, and less susceptible to management influences (Karamanou and Vafeas 2005; Li et al. 2012; Spira 1999). ${ }^{4}$ A high-quality audit committee is more effective at monitoring management by providing strong oversight of the internal control environment (Goodwin 2003; Raghunandan, Rama, and Read 2001) and is more willing to confront and probe management (Cohen, Krishnamoorthy, and Wright 2010).

We expect that a high-quality audit committee reduces the likelihood of external whistleblowing compared with internal reporting in two ways. First, a high-quality audit committee is likely to ensure that a whistle-blowing system is properly implemented to receive internal reports of misconduct. Studies have found that a higher quality audit committee is associated with stronger internal controls (Krishnan 2005; Zhang et al. 2007) and is more likely to review the results of internal auditing (Raghunandan et al. 2001). By setting a strong tone at the top and being an effective monitor of the internal control environment, a high-quality audit committee is more likely to ensure that a good internal reporting system is implemented. This will encourage greater internal reporting of misconduct and help to ensure reports of misconduct are promptly resolved, in turn reducing the likelihood of external whistle-blowing.

Second, a high-quality audit committee is likely to enhance organizational responsiveness to internal reports. When the audit committee is of a higher quality, there are more frequent interactions with the board, management, internal and external auditors (Cohen et al. 2010; Goodwin 2003; Goodwin and Yeo 2001). For example, Raghunandan et al. (2001) found that higher quality audit committees are more likely to have longer meetings with the chief internal auditor, ensure there is private access to the chief internal auditor, and review internal auditing results. With better communication and greater information sharing, internal reports are more likely to be properly received

\footnotetext{
${ }^{4}$ For a more comprehensive review of research on audit committees, refer to Tepalagul and Lin (2015).
} 
and promptly addressed. A high-quality audit committee is also likely to make better decisions when investigating internal reports because a higher quality audit committee is more objective and less susceptible to management influences (Karamanou and Vafeas 2005; Li et al. 2012; Spira 1999). Further, a high-quality audit committee is more likely to ensure that internal deficiencies are resolved and remediated (Gendron and Bedard 2006; Goh 2009). Thus, a higher quality audit committee is potentially more effective at ensuring that issues are properly resolved internally. When internal reports are properly managed, the outcome is more likely to be satisfactory to the whistle-blower, which potentially reduces external whistle-blowing. Insofar that a higher quality audit committee facilitates internal reporting and whistle-blowing investigation, having a higher quality audit committee is likely to decrease the likelihood of external whistle-blowing. Based on the discussion above, our first hypothesis is:

H1: The likelihood of external whistle-blowing relative to internal reporting is lower when the audit committee is of a higher quality.

\section{The Audit Committee and Retaliation Against a Whistle-blower}

Whistle-blowers who report internally or externally may be retaliated against (Near and Miceli 2008; Rehg et al. 2008). Employers have been found to retaliate against a whistle-blower as a means of controlling their employees to maintain the power-dependence relationships within the organization (Near and Jensen 1983; Parmerlee, Near, and Jensen 1982), or to discredit or silence the whistle-blower (Mesmer-Magnus and Viswesvaran 2005; Near and Jensen 1983; Parmerlee et al. 1982; Rehg et al. 2008). We expect a high-quality audit committee to be associated with a lower likelihood of retaliation because a high-quality audit committee is known to provide stronger oversight and deter management from acting unethically, such as by constraining aggressive financial reporting or corporate misreporting (Abbott et al. 2000; Abbott, Parker, and Peters 2004; Bédard, Chtourou, and Courteau 2004; Xie et al. 2003).

By providing stronger oversight, a high-quality audit committee is likely to reduce the likelihood that management would undertake detrimental actions and retaliate against the internal whistle-blower by discrediting or silencing the whistle-blower to cover up misconduct. Insofar that a 
high-quality audit committee can provide strong oversight and curtail management from undertaking undesirable actions against the whistle-blower, there would be a lower likelihood of whistle-blowing retaliation. ${ }^{5}$ Based on the discussion above, our second hypothesis is:

H2: The likelihood of whistle-blowing retaliation is lower when the audit committee is of a higher quality.

Although we expect that a high-quality audit committee will reduce the likelihood of external whistle-blowing and the likelihood of whistle-blowing retaliation, an alternate argument can be made that a high-quality audit committee could increase the likelihood of external whistle-blowing and retaliation. For example, because audit committee members bear reputational penalties when a case of corporate misreporting is revealed (Fich and Shivdasani 2007; Srinivasan 2005), even when they are innocent of corporate wrongdoings (Cowen and Marcel 2011), audit committee members with higher reputational capital at risk might have incentives to stymie or ignore an internal whistle-blowing allegation. Therefore, we believe it is important to test the relationship between audit committee quality and whistle-blowing.

\section{RESEARCH METHOD AND SAMPLE}

\section{Sample}

We adopt an archival approach similar to Bowen et al. (2010) and construct a sample by gathering cases of financial allegations in listed Australian firms that were reported in the press. ${ }^{6} \mathrm{~A}$ key difference to Bowen et al. (2010) is that while they examined only employee whistle-blowing, our

\footnotetext{
${ }^{5}$ It is possible that a greater likelihood of retaliation could also reduce the likelihood of external whistleblowing. The findings in prior research are not consistent with this expectation (Miceli, Near, and Dworkin 2009; Rehg et al. 2008).

${ }^{6}$ Press reports provide new information on the alleged misconduct beyond that obtained from other sources (Miller 2006) and avoid possible self-report biases associated with surveys (Dworkin and Baucus 1998). Although the use of press reports may create a potential bias toward frauds in larger firms (Miller 2006) and frauds that are more important or newsworthy (Bowen et al. 2010), an archival approach potentially provides more objective evidence than a survey approach.
} 
sample consists of both employee and non-employee whistle-blowing, as non-employees are an important source of whistle-blowing reports (Dyck et al. 2010; Read and Rama 2003). ${ }^{7}$

Press reports of financial allegations were collected by conducting searches on Factiva using terms such as "fraud”, “financial fraud”, “theft”, “misappropriation”, “corruption”, “defraud”, “bribery”, “kickbacks”, “rort”, “insider trading”, “corporate fraud”, or “fraudulent reporting”. The searches covered the entire text of the news article; the sample period was 1992 to 2015. For each allegation of financial misconduct, related news articles were sourced and read to identify when the financial misconduct was alleged, the type of alleged financial misconduct, how it was uncovered, its perpetrator(s), and its cost. These items were coded for use in subsequent analyses. ${ }^{8}$

We identified cases of internal reporting and external whistle-blowing that were observable from the press reports. An allegation was attributed as an internal report if the allegation was referenced in the press report as having stemmed from an internal tip, audit, review, or internal investigation, or if it was otherwise uncovered internally by the firm. That is, these cases were not publicly revealed by the whistle-blower.

As illustrated in Figure 1, internally reported misconduct was observable from press reports in two situations. First, internally reported misconduct was publicly observable when the press reported on ongoing court hearings that arose from an internally reported misconduct. Second, an internally reported misconduct was observable when the press picked up and reported news stories following a firm's disclosure to the ASX about the incidence of an internally reported misconduct. An allegation was attributed as external whistle-blowing when misconduct was revealed by the whistle-blower to parties outside the organization, such as the media, regulators, or parliamentary members, as referenced in the press. External whistle-blowing cases involved either an allegation that was preceded by an

\footnotetext{
${ }^{7}$ Johnson et al. (2004, 353) contend that “organizations increasingly rely on extensive relationships and networks of external groups and agencies ... Information about problems or wrongdoings is, therefore, increasingly likely to come from within these networks." We examine differences between employee and non-employee whistle-blowing in the additional analysis.

${ }^{8}$ An independent coder classified a sub-sample of 10 percent of the observations and the resulting interrater reliability was reasonably high (Kappa $=0.848, p<0.01$ ).
} 
unsuccessful attempt at internal whistle-blowing, or the whistle-blower directly disclosing an allegation outside the organization. ${ }^{9}$

(Insert Figure 1 here)

The sample selection is summarized in Table 1. A total of 554 financial allegations were obtained from the searches on Factiva. There were instances where a firm experienced more than one allegation of financial misconduct in a given year. When there were multiple observations in the same year, only one financial misconduct allegation was retained in the sample, and 50 financial allegations were excluded. ${ }^{10}$ Financial data were sourced from Morningstar's DatAnalysis and the Connect 4 database; we excluded another 32 allegations because of insufficient data. Lastly, 154 allegations that were not attributed to external whistle-blowing or internal reporting were eliminated, ${ }^{11}$ constraining the final sample to 318 observations. Of the 318 financial allegations, most financial allegations were uncovered by internal reporting to management (221/318, 69 percent). The remaining 31 percent of allegations (97/318) were revealed by external whistle-blowing. The percentage of external whistleblowing cases in our sample was comparable to the rate of 39 percent reported among Australian public sector employees (Brown, Mazurski, and Olsen 2008).

\section{(Insert Table 1 here)}

Table 2 reports the frequency of the type of alleged financial misconduct, as reported in the press, in our sample. The most common type of financial misconduct was the misappropriation of funds or assets (53 percent), followed by the misuse of funds (10 percent) and price-fixing (10 percent). These findings are in line with a survey that found misappropriation of assets to be the most commonly perpetrated fraud within firms in Australia and New Zealand (KPMG 2010). Compared with internal

\footnotetext{
${ }^{9}$ While in many cases the press reported that an initial internal whistle-blowing report was made, we could not conclusively determine that all external whistle-blowing was first reported internally.

${ }^{10}$ As a sensitivity analysis, we re-estimated the model by (1) substituting the cases chosen for inclusion with the cases excluded, and (2) retaining all excluded cases. The results from these two analyses are qualitatively unchanged from the primary results of this study.

${ }^{11}$ The 154 excluded cases consisted of cases reported as uncovered by authorities, such as domestic regulators, the police, or international regulators (98 cases) and private litigation (56 cases).
} 
reporting, financial allegations involving bribery $(p<0.01)$, misuse of funds $(p<0.01)$, and pricefixing $(p<0.01)$ were more likely to result in external whistle-blowing. Internal reporting was more likely to uncover alleged misconduct involving misappropriation of funds or assets $(p<0.01)$.

(Insert Table 2 here)

\section{Variables}

\section{Dependent Variable-Internal Versus External Whistle-blowing}

We use an indicator variable, extwb, to capture whether a financial allegation resulted in external whistle-blowing or internal reporting. extwb is an indicator variable coded " 1 " if the alleged financial misconduct, as referenced in the press, was revealed because of external whistle-blowing, and " 0 " when referenced to have been revealed because of internal reporting. An allegation was attributed as external whistle-blowing when the whistle-blower reported misconduct to an external party (such as the media, regulators, or parliamentary members), as referenced in the press. An allegation was attributed as an internal report if the allegation arose from an internal tip, audit, review or internal investigation, or was otherwise uncovered internally by the firm, as referenced in the press.

\section{Dependent Variable - Whistle-blowing Retaliation}

Whistle-blowing retaliation is an undesirable action taken against a whistle-blower who reports wrongdoing internally or externally (Near and Miceli 2008; Rehg et al. 2008). Retaliation against whistle-blowers can be formal and official, such as job termination and selective downsizing, or it can be informal and unofficial, such as social confrontation and threat (Bjørkelo and Matthiesen 2011). To capture the incidence of whistle-blowing retaliation, we code an indicator variable retaliated " 1 " if it was reported in the press that the whistle-blower suffered any form of formal or informal retaliation, and "0" otherwise.

A limitation of relying on press reports to identify cases of retaliation is that retaliation can take many forms and can occur over a long period, such that the retaliation event is not publicly recorded. Hence, we conducted searches on Factiva using the name of the whistle-blower and the company 
involved to identify all possible retaliatory actions that may have occurred across time; however, the measure of observed retaliation must be considered a subset of retaliation that occurs. ${ }^{12}$

\section{Variable of Interest-Audit Committee Quality}

Audit committee quality is captured using measures of audit committee independence, expertise and meeting frequency (as a proxy for diligence) (Bédard and Gendron 2010; Gendron and Bédard 2006). Independence (acind) is measured by the percentage of audit committee members that are independent (Chen, Moroney, and Houghton 2005) in the year prior to the financial allegation. An independent audit committee member is one who is a non-executive and without any related party transactions with the firm (Koh, Laplante, and Tong 2007). Expertise (acexp) is measured by the percentage of audit committee members with professional accounting or finance qualifications (Chen et al. 2005; Goodwin-Stewart and Kent 2006) in the year prior to the financial allegation. Meeting frequency (acmeet) is measured by the number of audit committee meetings (Barua, Rama, and Sharma 2010) in the year prior to the financial allegation. ${ }^{13}$ We use a composite measure of audit quality, $a c$, derived by factor analysis of acind, acexp, and acmeet. Data on the number, independence, and qualifications of audit committee members, and number of audit committee meetings, are obtained from annual reports in the Connect 4 database.

\section{Model-Whistle-blowing Reporting Channel}

We model the likelihood of external whistle-blowing based upon the model of the probability of whistle-blowing developed by Bowen et al. (2010). ${ }^{14}$ We include firm size (size) because larger firms

\footnotetext{
${ }^{12}$ To the extent that retaliation is unobserved, we might expect retaliation is less likely to be observed for internal reporting relative to external whistle-blowing. Future research is needed, where data permits, to consider the extent and determinants of retaliatory actions that do not rise to a level where they are externally disclosed, and the governance mechanisms that can constrain such behavior.

${ }^{13}$ While diligence includes other factors, such as preparation, attentiveness, and participation during meetings, the only factor that is publicly observable is number of meetings (Carcello, Hermanson, Neal, and Riley Jr 2002).

${ }^{14}$ The model employed in Bowen et al. (2010) included firm reputation, capital market pressure, downsizing, and internal control weaknesses. There was insufficient data to include these variables in our study. These variables were generally not found to be significant in the press sample employed by Bowen et al. (2010).
} 
are more prone to regulatory and media scrutiny and, thus, employees are likely to have greater confidence reporting to those parties (Bowen et al. 2010). Size is measured as the logarithm of total assets in dollars in the year prior to the fraud allegation. We include growth of the firm (growth) because rapidly growing firms are likely to have poorer internal controls (Bowen et al. 2010; Doyle, Ge, and McVay 2007), thus increasing the likelihood of an external whistle-blowing event. The growth of the firm (growth) is measured by the average change in revenue over the past three years prior to the financial allegation. Firms with poorer stock market performance (pastperf) are more likely to be targeted by whistle-blowers because such firms tend to be more newsworthy to the media (Bowen et al. 2010). Past performance (pastperf) is measured as the market-adjusted buy-and-hold returns over the past one year prior to the financial allegation. We include firm complexity (complex) because complex firms are more likely to have unclear internal communication channels, increasing the likelihood of external whistle-blowing (Bowen et al. 2010). We measure firm complexity (complex) as the average of industry and geographical complexity, where industry complexity is calculated as one minus the industry segment-sales-based Herfindahl index; geographical complexity is calculated as one minus the geographical segment-sales-based Herfindahl index.

To control for board characteristics, we include the proportion of independent directors on the board in the year prior to the financial allegation (inddir) and brdmeet, which captures the number of board meetings in the year prior to the financial allegation. Data on total assets, revenue, share price, proportion of independent directors, board meetings, firm segmentation, and segment revenues are sourced from annual reports obtained from Morningstar's DatAnalysis and the Connect 4 database. The severity of fraud affects the likelihood of whistle-blowing (Schultz et al. 1993; Warr 1989); therefore, we include frdamt which is the logarithm of fraud amount in dollars, as reported in the press. ${ }^{15} \mathrm{We}$ include industry (defined by the first two digits of GICS code) fixed effects, and standard errors are clustered by firms to control for heteroskedasticity (White 1980). To investigate whether audit committee quality affects the likelihood of external whistle-blowing compared with internal reporting, we estimate the following model (with firm and year subscripts suppressed):

${ }^{15}$ Whistleblowing studies have also identified that moral wrongfulness affects the whistleblowing decision (Warr 1989). We were unable to obtain archival data on moral wrongfulness. 


$$
\begin{aligned}
\operatorname{Pr}(\text { extwb })= & \beta_{0}+\beta_{1} a c+\beta_{2} \text { size }+\beta_{3} \text { growth }+\beta_{4} \text { complex }+\beta_{5} \text { pastperf }+\beta_{6} \text { inddir }+ \\
& \beta_{7} \text { brdmeet }+\beta_{8} \text { frdamt }+ \text { Eindustry }+\varepsilon
\end{aligned}
$$

See the appendix for variable definitions.

\section{Model-Whistle-blowing Retaliation}

We examine whether the quality of the audit committee is associated with the likelihood that a whistle-blower was retaliated against (retaliated) using a logit regression. Our model include firm size (size) and firm complexity (complex) because bigger firms are associated with less retaliation (Miceli, Rehg, Near, and Ryan 1999). We include firm growth (growth) and past share performance (pastperf) because retaliation often occurs when stopping the misconduct harms the organization (Miceli and Near 1994), which is more likely when an organization is performing poorly. We control for corporate governance and include the percentage of independent directors (inddir) to proxy for board independence, and number of board meetings (brdmeet) to proxy for board diligence. We also include frdamt because severity of fraud increases the likelihood of retaliation (Near, Baucus, and Miceli 1993) and industry fixed effects. These variables are as previously defined, and are described in the appendix. To investigate whether audit committee quality affects the likelihood of whistle-blowing retaliation, we estimate the following model (with firm and year subscripts suppressed):

$$
\begin{aligned}
\operatorname{Pr}(\text { retaliated })= & \beta_{0}+\beta_{1} \text { ac }+\beta_{2} \text { size }+\beta_{3} \text { growth }+\beta_{4} \text { complex }+\beta_{5} \text { pastperf }+\beta_{6} \text { inddir }+ \\
& \beta_{7} \text { brdmeet }+\beta_{8} \text { frdamt }+ \text { Eindustry }+\varepsilon
\end{aligned}
$$

\section{Descriptive Statistics}

Table 3 presents descriptive statistics for the sample. The average firm in the sample has total assets of \$76.7 million, experienced positive growth (11.1 percent), positive past share performance (17.6 percent), a proportion of 77 percent independent directors on the board, and the board met 12 times a year. The average firm has a proportion of 85 percent independent directors on the audit committee, a proportion of 38 percent financial experts on the audit committee, and an audit committee that met 5 times a year. As would be expected, the sample based upon press reports capture larger and more newsworthy frauds. The reported average cost of alleged fraud in our sample is AUD \$35,700,000. 
The average amount of fraud reported in a global study of fraud by the ACFE (2016) was USD\$2.70 million (approximately AUD\$3.60 million); a recent survey of frauds for firms in Australia and New Zealand indicated an average cost of AUD\$3.08 million (KPMG 2013). Therefore, our sample is representative of the larger frauds perpetrated in firms. The rate of retaliation in our sample is 12 percent (38/318). As noted above, this rate of reported incidents of retaliation likely only captures a fraction of the actual retaliatory actions against whistle-blowers.

In comparison with internal reporting cases, firms subjected to external whistle-blowing have fewer independent directors on the audit committee $(p<0.01)$ and on the board $(p<0.05)$, fewer financial experts on the audit committee ( $p<0.05)$, and audit committees that met less often $(p<0.05)$. External whistle-blowing firms have greater firm complexity $(p<0.01)$ and stronger past share performance $(p<0.01)$. Retaliation was more likely to occur when there were fewer independent directors on the audit committee $(p<0.01)$, when fraud was more severe $(p<0.01)$, and when a firm had stronger past share performance $(p<0.01)$. Retaliation occurred less often when boards met less frequently $(p<0.10)$ and when a firm was experiencing stronger growth $(p<0.10)$.

(Insert Table 3 here)

\section{RESULTS}

\section{Audit Committee Quality and Whistle-blowing Reporting Channel}

The results of Model (1) are reported in Column (1) of Table 4. The model has significant explanatory power $(p<0.01)$ and an adjusted Pseudo $\mathrm{R}^{2}$ of 0.329 . H1 posits that a high-quality audit committee is associated with lower likelihood of external whistle-blowing as compared with internal whistle-blowing. Consistent with $\mathrm{H} 1$, the coefficient on $a c$ is significantly negative (coefficient -1.289 , $p<0.01$ ), indicating that a high-quality audit committee is associated with a lower likelihood of external whistle-blowing as compared with internal reporting. We next examine different components of the audit committee: audit committee independence (acind), audit committee expertise (acexp), and audit committee diligence (acmeet). The results of the components of audit committee on the likelihood of external whistle-blowing are reported in Column (2). We find a significant negative coefficient on acind (coefficient $-2.295, p<0.01$ ) and acmeet (coefficient $-0.172, p<0.05$ ). The coefficient on acexp 
is not significant. Our results suggest audit committee independence and audit committee diligence are associated with a lower likelihood of external whistle-blowing as compared with internal reporting.

For the control variables, we find that the coefficients on size, complex, pastperf, and frdamt are significantly positive. The results suggest that compared with internal whistle-blowing, external whistle-blowing is more likely to occur when firms are bigger, more complex, and have stronger past share performance, and when fraud is more severe. Our findings provide confirmatory evidence to Bowen et al. (2010) of the characteristics of firms that experience external whistle-blowing with respect to firm size, past share performance, and firm complexity. We also find a significant negative coefficient on inddir, indicating that the likelihood of external whistle-blowing compared with internal reporting is lower when the proportion of independent directors is greater.

(Insert Table 4 here) 


\section{Audit Committee Quality and Whistle-blowing Retaliation}

The results of Model (2) are reported in Column (1) of Table 5. The model has significant explanatory power $(p<0.01)$ and an adjusted Pseudo $\mathrm{R}^{2}$ of 0.227 . H2 posits that a high-quality audit committee is associated with lower likelihood of whistle-blowing retaliation. Consistent with H2, the coefficient on $a c$ is significantly negative (coefficient $-0.795, p<0.05$ ), indicating that a high-quality audit committee is associated with a lower likelihood of retaliation against the whistle-blower. The results of the components of audit committee on the likelihood of retaliation are reported in Column (2). We find a significant negative coefficient on acind (coefficient $-1.605, p<0.05$ ) and acmeet (coefficient $-0.215, p<0.10$ ). The coefficient on acexp is not significant. Our results indicate that audit committee independence and audit committee diligence are associated with a lower likelihood of retaliation against the whistle-blower. Turning to our control variables, we find the coefficient on complex $(p<0.10)$ and frdamt $(p<0.01)$ to be significantly positive, indicating that whistle-blowers face a greater likelihood of retaliation when there is greater firm complexity and when alleged fraud is more severe. Overall, our results suggest that a high-quality audit committee provides better oversight of whistle-blowing by protecting whistle-blowers against retaliation.

(Insert Table 5 here)

\section{ADDITIONAL ANALYSIS}

\section{Audit Committee Quality and Strength of Whistle-blowing System}

We predicted that a high-quality audit committee would reduce the likelihood of external whistle-blowing because stronger oversight would lead to implementation of an effective internal whistle-blowing system. We next investigate whether the quality of the audit committee is associated with the implementation of a strong whistle-blowing system (wbsys). To capture the strength of a whistle-blowing system (wbsys), we construct an index based on observable measures of a reporting system from a firm's whistle-blowing policy (Baloria et al. 2016; Lee and Fargher 2013). ${ }^{16}$ We

\footnotetext{
${ }^{16}$ We cannot directly observe the strength of the whistle-blowing system; therefore, we rely on corporate disclosures on whistle-blowing policies because an effective whistle-blowing system would be expected to provide employees with a high level of disclosure regarding the whistle-blowing system (Baloria et al. 2016; Lee and Fargher 2013).
} 
reviewed the whistle-blowing and professional literature, and identified four key dimensions of a strong internal whistle-blowing system: provision of a reporting hotline (hotline), the ability to report anonymously (anon), designating a whistle-blowing officer (wbo), and providing protection to the whistle-blower (protect). ${ }^{17}$ We conduct a factor analysis based on hotline, anon, wbo and protect. An indicator variable (hotline) is coded " 1 " if the firm provided a hotline in the year prior to the financial allegation, as reported in the annual report, and " 0 ” otherwise. An indicator variable ( $w b o$ ) is coded " 1 " if the firm appointed a designated whistle-blowing officer in the year prior to the financial allegation, as reported in the annual report, and " 0 " otherwise. An indicator variable (anon) is coded " 1 " if provision of an anonymous reporting system was disclosed in the annual report of the year prior to the financial allegation, and " 0 " otherwise. An indicator variable (protect) is coded " 1 " if management disclosed protection for internal reporting in the annual report, and "0" otherwise. The computed factor scores form the variable wbsys. A higher score represents greater strength of the corporate whistleblowing system. Data on a firm's disclosures of its internal whistle-blowing system are sourced from the annual reports obtained from the Connect 4 database.

Following prior literature (Lee and Fargher 2013), we include economic and corporate governance control variables that are likely to affect the implementation of a whistle-blowing system: firm size (size), growth (growth), complexity (complex), past share performance (pastperf), percentage of independent directors (inddir), number of board meetings (brdmeet), and industry fixed effects. We estimate the following OLS model (with firm and year subscripts suppressed):

$$
\begin{aligned}
\text { wbsys }= & \beta_{0}+\beta_{1} \text { ac }+\beta_{2} \text { size }+\beta_{3} \text { growth }+\beta_{4} \text { complex }+\beta_{5} \text { pastperf }+\beta_{6} \text { inddir }+\beta_{7} \text { brdmeet }+ \\
& \text { Eindustry }+\varepsilon
\end{aligned}
$$

See the appendix for variable definitions.

The results of Model (3) are reported in Column (1) of Table 6. The model has significant explanatory power $(p<0.01)$ and an adjusted $\mathrm{R}^{2}$ of 0.297 . Consistent with our expectations, we find a

\footnotetext{
${ }^{17}$ We include these variables because a hotline channel helps to facilitate whistle-blowing (Miceli et al. 2009), the ability to report anonymously reduces perceived costs of reporting (Ayers and Kaplan 2005; Kaplan, Pany, Samuels, and Zhang 2009), a designated whistle-blowing officer enhances perception that there is a responsible person in-charge for whistle-blowing matters (Lewis and Spencer 2001), and providing whistle-blowing protection is important because the threat of retaliation is a key deterrent to whistle-blowing (Arnold and Ponemon 1991; Cassematis and Wortley 2013).
} 
significant positive coefficient on $a c$ (coefficient 0.392, $p<0.05$ ), indicating that a high-quality audit committee is associated with the implementation of a stronger internal whistle-blowing system. As for the different components of the audit committee, the results reported in Column (2) show a significant positive coefficient on acind (coefficient 0.650, $p<0.05$ ) and acexp (coefficient 1.004, $p<0.05$ ). The coefficient on acmeet is not significant. Our results indicate that audit committee independence and expertise are associated with the implementation of a stronger internal whistle-blowing system.

For the control variables, we find significant coefficients on size, complex and growth. The results indicate that firms that are bigger and more complex are more likely to implement a stronger internal whistle-blowing system. This is consistent with research that has found that larger firms with more business segments are more likely to provide a hotline channel (Lee and Fargher 2013). In contrast, firms that experience higher growth are less likely to implement a stronger internal whistleblowing system. This is consistent with research that has found that rapidly growing firms have poorer internal controls (Ashbaugh-Skaife, Collins, and Kinney Jr 2007; Doyle et al. 2007).

(Insert Table 6 here)

\section{Audit Committee Quality, Whistle-blowing System, Retaliation, and Reporting Channel}

We conduct a path analysis to provide further evidence that audit committee quality affects the whistle-blowing reporting channel (internal versus external whistle-blowing) by ensuring the implementation of a stronger internal whistle-blowing system and reducing the likelihood of retaliation. The control variables included in the path analysis model are consistent with the ones specified in Models (1)-(3). The path analysis results are reported in Panel A of Table 7.

Consistent with our main results, we find that a higher quality audit committee is associated with less external compared with internal reporting $(p<0.01)$. Further, we find that a higher quality audit committee is associated with a stronger internal whistle-blowing system $(p<0.10)$, and a strong internal whistle-blowing system in turn reduces external compared with internal reporting $(p<0.10)$. This finding provides evidence that a higher quality audit committee affects the whistle-blowing reporting channel by ensuring implementation of a strong internal whistle-blowing system. Consistent with our main results, we find that a higher quality audit committee is associated with less whistle- 
blowing retaliation $(p<0.01)$. We also find that the incidence of whistle-blowing retaliation (retaliated) is positively associated with external whistle-blowing $(p<0.01)$. This is consistent with prior studies that found that whistle-blowers who experience retaliation (or perceived retaliation) for reporting misconduct internally tend to report externally (Arnold and Ponemon 1991; Callahan and Dworkin 1994; Near et al. 1993; Rehg et al. 2008). Taken together, these results provide evidence that a higher quality audit committee is associated with establishing a stronger internal whistle-blowing system and a lower likelihood of retaliation, in turn reducing the likelihood of external compared with internal reporting.

(Insert Table 7 here)

\section{Employee Versus Non-employee Whistle-blowing}

Our sample consists of employee and non-employee whistle-blowers. We next consider whether the effect of audit committee quality on the likelihood of whistle-blowing and whistle-blowing retaliation depended on whether the whistle-blower was an employee or not. Individuals are more likely to trust in-group members and are warier of out-group members (Foddy, Platow, and Yamagishi 2009; McAllister 1995; Williams 2001). Thus, it is possible that an audit committee is more likely to distrust internal whistle-blowing allegations made by non-employees than employees. In turn, we would expect that when non-employees blow the whistle, the audit committee would be less likely to ensure that reports made to the firm are properly responded to or protect non-employees against retaliation. We partition our sample into two sub-samples, consisting of employee whistle-blowing $(n=227)$ and nonemployee whistle-blowing $(n=91)$. The employee whistle-blowing sub-sample include cases of misconduct reported (either internally or externally) by organizational members, while the nonemployee whistle-blowing sub-sample include cases of misconduct reported (either internally or externally) by non-organizational members, such as competitors, customers, and suppliers. As reported in Panel B of Table 7, we find a significant coefficient on $a c$ for employee whistle-blowing with regard to the likelihood of whistle-blowing $(p<0.05)$ and likelihood of retaliation $(p<0.05)$. We do not find the coefficient on $a c$ to be significant for non-employee whistle-blowing $(p>0.10)$. Together, these 
results suggest that a high-quality audit committee reduces external whistle-blowing and whistleblowing retaliation for employees, but not for non-employees.

\section{Alternative Explanations}

A plausible explanation for our findings is that audit committee quality acts as a proxy for good overall governance. While we included corporate governance variables (inddir and brdmeet) in our main model, we further consider an overall measure of good corporate governance. Prior studies have suggested that a good corporate board is active and meets frequently (brdmeet), has greater board independence (inddir), is not too large to be effective (brdsize), is absent of CEO duality (ceoduality), and has an independent board chairman (indchair) (Osma and Guillamón-Saorín 2011; Van den Berghe and Levrau 2004). We conduct a factor analysis on brdmeet, inddir, brdsize, ceoduality, and indchair to compute an overall corporate governance measure (corpgov), whereby a higher score represents better corporate governance. brdsize is the number of directors on the board, ceoduality is an indicator variable coded " 1 " if the chairperson is not the CEO and "0" otherwise, indchair is an indicator variable coded " 1 " if the chairperson is an independent director and " 0 " otherwise, and brdmeet and inddir are as previously defined.

Our results are presented in Panel C of Table 7. As reported in Column (1), we find that good overall corporate governance reduces the likelihood of external whistle-blowing. Our primary findings - that a high-quality audit committee reduces the likelihood of external whistle-blowinghold. For whistle-blowing retaliation, reported in Column (2), we do not find whistle-blowing retaliation to be associated with the overall measure of corporate governance. Our primary findings - that a highquality audit committee reduces the likelihood of whistle-blowing retaliation—remain robust to the control for good overall corporate governance.

Another plausible explanation for our findings is that audit committee quality may capture the extent of CEO power, as CEO power may be associated with audit committee effectiveness (Raghunandan and Rama 2007). To address this concern, we include CEO duality (ceoduality) in Models (1) and (2). As reported in Panel D of Table 7, after controlling for CEO duality, our primary results still hold; namely, a high-quality audit committee is associated with a lower likelihood of 
external whistle-blowing compared with internal whistle-blowing $(p<0.01)$, and a lower likelihood of whistle-blowing retaliation $(p<0.05)$. We also do not find evidence that CEO duality affects the likelihood of external whistle-blowing compared with internal whistle-blowing $(p>0.10)$ or the likelihood of whistle-blowing retaliation $(p>0.10)$.

Another plausible explanation for our finding is that audit committee quality may be capturing the quality of monitoring by shareholders, as stringent shareholder monitoring increases audit committee quality (Méndez and García 2007). To address this concern, we include the percentage held by top 20 shareholders (sharehold) in Models (1) and (2). As reported in Panel E of Table 7, our primary results hold after controlling for monitoring by shareholders. Another possible explanation for our finding is that audit committee quality may be capturing audit quality (Abbott and Parker 2000), in which case our results would be attributable to auditor quality rather than quality of the audit committee. To address this concern, we include a dummy for Big 4 auditor (big4) and the natural logarithm of audit fees paid (auditfee) in Models (1) and (2). As reported in Panel F of Table 7, our results remain robust to controlling for auditor quality.

\section{Other Robustness Checks}

We estimated our results (Models 1 and 2) using a logit model. Our results are not sensitive to use of a probit specification. In 2004, Australia introduced the Corporate Law Economic Reform Program Act (CLERP 9), which enhanced protection for whistle-blowers. To control for effects of CLERP 9, in Models (1) and (2) we include a variable, clerp9, that is coded " 1 " for observations in the year 2004 onwards, and "0" otherwise. Untabulated results indicate that our primary results hold. We also find a significant negative coefficient on $\operatorname{clerp9}(p<0.05)$, suggesting a lower likelihood of external whistle-blowing post-CLERP 9, but we do not find that CLERP 9 affects the likelihood of retaliation.

Bowen et al. (2010) suggested, but did not find, that capital market pressure significantly affects whistle-blowing. As a test of robustness, in Models (1) and (2) we include the need for financing (finneed), computed as the proceeds for share issue and borrowings for the year over total assets. Our sample reduced to 307. Similar to Bowen et al. (2010), untabulated results indicate that the coefficient 
on finneed is not significant, and our primary results hold. The tendency to report fraud to the police in New South Wales (NSW) may be greater relative to other states because failing to report a "serious offense” is itself considered an offense under Section 316 of the Crimes Act 1900 (NSW) (Smith 2008). We examine the robustness of our findings to any NSW effect by coding an indicator variable, nsw, "1" if the fraud was perpetrated in NSW and "0" otherwise. The results (untabulated) indicate that the coefficient on the $n s w$ variable is not significant (coefficient $=-0.081, \mathrm{z}=-0.049$ ), and our primary results remain robust.

\section{CONCLUSION}

The purpose of this study is to examine the role of the audit committee in their oversight of whistle-blowing. Specifically, we examine whether the quality of the audit committee was associated with a reduced likelihood of external whistle-blowing (compared with internal reporting), and a reduced likelihood of retaliation. We constructed a sample based on 318 financial allegations reported in the press. Press reports allowed us to identify both external whistle-blowing and public reports of internal reporting. This provided an opportunity to identify organizational factors associated with external whistle-blowing relative to internal reporting.

Our results indicate that a high-quality audit committee is associated with a lower likelihood of external whistle-blowing compared with internal whistle-blowing and a lower likelihood of retaliation. We also find that an audit committee of higher quality is associated with the implementation of a stronger internal whistle-blowing system. A path analysis provides further evidence that a higher quality audit committee is associated with establishing a stronger internal whistle-blowing system and a lower likelihood of retaliation; in turn, these two factors reduce the likelihood of external compared with internal reporting. While our research design does not allow us to draw inferences regarding causality, our findings do suggest that the quality of the audit committee plays an important role in their oversight of the whistle-blowing process.

We also examined conditions in which the audit committee might play a more important or less important role in the whistle-blowing process. Specifically, we compared employee versus nonemployee whistle-blowing. We find that audit committee quality affects whistle-blowing by employees, 
but not non-employees. We have provided evidence of differences in the predictors of external whistleblowing for employees and non-employees. Future research could further investigate the factors that affect non-employee whistle-blowing, as non-employees are important sources of whistle-blowing (Dyck et al. 2010; Read and Rama 2003).

The following are limitations to our study and avenues for future research. Because of our reliance on press reports, the incidences of internal reports were likely to include the larger, more newsworthy events. Internally reported frauds that go unreported cannot be studied with this approach (Smith 2008). More specifically, the frauds in our sample represent major frauds; hence, our results may not be generalizable to smaller frauds or unreported frauds. While the size of the firm and the reported magnitude of the alleged fraudulent activity are included in the analysis, our results must be interpreted with respect to this potential source of bias. Another limitation of relying on press reports is that many retaliation events likely go unreported in the press due to the nature of retaliation or the period of retaliation. Future research from a variety of methodological approaches is needed to extend understanding of the reporting of misconduct and, in particular, the management and governance mechanisms that can resolve issues to avoid the costlier external reporting of financial misconduct.

Another fruitful avenue for research is to explore the audit committee members' decisionmaking processes following the receipt of whistle-blowing reports. As noted in Carcello et al. (2011), although archival methods are the dominant research method in audit committee research and are suitable for examining audit committee characteristics or outputs, they are not suitable for analyzing processes. Future research could explore how decisions relating to whistle-blowing reports are made by audit committee members, using experiments or interviews to provide more insight into the role of the audit committee in providing oversight of whistle-blowing. 


\section{References}

Abbott, L. J., Y. Park, and S. Parker. 2000. The effects of audit committee activity and independence on corporate fraud. Managerial Finance 26 (11):55-68.

Abbott, L. J., and S. Parker. 2000. Auditor selection and audit committee characteristics. Auditing: A Journal of Practice \& Theory 19 (2):47-66.

Abbott, L. J., S. Parker, and G. F. Peters. 2004. Audit committee characteristics and restatements. Auditing: A Journal of Practice \& Theory 23 (1):69-87.

Andon, P., C. Free, R. Jidin, G. S. Monroe, and M. J. Turner. 2016. The impact of financial incentives and perceptions of seriousness on whistleblowing intention. Journal of Business Ethics, Forthcoming.

Arnold, D., and L. Ponemon. 1991. Internal auditors' perceptions of whistle-blowing and the influence of moral reasoning: An experiment. Auditing: A Journal of Practice and Theory 10 (2):1-15.

Ashbaugh-Skaife, H., D. W. Collins, and W. R. Kinney Jr. 2007. The discovery and reporting of internal control deficiencies prior to SOX-mandated audits. Journal of Accounting and Economics 44 (1-2):166-192.

ASIC. 2016. Whistleblowers-company officeholder obligations. Available at: Http://asic.Gov.Au/forbusiness/running-a-company/company-officeholder-duties/whistleblowers-companyofficeholder-obligations/.

Association of Certified Fraud Examiners. 2016. Report to the nations on occupational fraud and abuse: 2016 global fraud survey. Austin, Texas.

Ayers, S., and S. E. Kaplan. 2005. Wrongdoing by consultants: An examination of employees' reporting intentions. Journal of Business Ethics 57 (2):121-137.

Baloria, V. P., C. A. Marquardt, and C. I. Wiedman. 2016. A lobbying approach to evaluating the whistleblower provisions of the Dodd-Frank Reform Act of 2010. Available at SSRN: http://ssrn.com/abstract $=1923310$.

Barnett, T., D. S. Cochran, and G. S. Taylor. 1993. The internal disclosure policies of private-sector employers: An initial look at their relationship to employee whistleblowing. Journal of Business Ethics 12 (2):127-136.

Barua, A., D. V. Rama, and V. Sharma. 2010. Audit committee characteristics and investment in internal auditing. Journal of Accounting and Public Policy 29 (5):503-513.

Beasley, M. S. 1996. An empirical analysis of the relation between the board of director composition and financial statement fraud. The Accounting Review 71 (4):443-465.

Beasley, M. S., J. V. Carcello, D. R. Hermanson, and T. L. Neal. 2009. The audit committee oversight process. Contemporary Accounting Research 26 (1):65-122.

Bédard, J., S. M. Chtourou, and L. Courteau. 2004. The effect of audit committee expertise, independence, and activity on aggressive earnings management. Auditing: A Journal of Practice \& Theory 23 (2):13-35.

Bédard, J., and Y. Gendron. 2010. Strengthening the financial reporting system: Can audit committees deliver? International Journal of Auditing 14 (2):174-210.

Berry, B. 2004. Organizational culture: A framework and strategies for facilitating employee whistleblowing. Employee Responsibilities and Rights Journal 16 (1):1-11.

Bierstaker, J. L., J. R. Cohen, F. T. DeZoort, and D. R. Hermanson. 2012. Audit committee compensation, fairness, and the resolution of accounting disagreements. Auditing: A Journal of Practice \& Theory 31 (2):131-150.

Bjørkelo, B., S. Einarsen, and S. B. Matthiesen. 2010. Predicting proactive behaviour at work: Exploring the role of personality as an antecedent of whistleblowing behaviour. Journal of Occupational and Organizational Psychology 83 (2):371-394.

Bjørkelo, B., and S. B. Matthiesen. 2011. Preventing and dealing with retaliation against whistleblowers. In Whistleblowing and Democratic Values, edited by D. L. W. Vandekerckhove: The International Whistleblowing Research Network, 127-149.

Bowen, R. M., A. C. Call, and S. Rajgopal. 2010. Whistle-blowing: Target firm characteristics and economic consequences. The Accounting Review 85 (4):1239-1271.

Brennan, N., and J. Kelly. 2007. A study of whistleblowing among trainee auditors. The British Accounting Review 39 (1):61-87. 
Brink, A. G., D. J. Lowe, and L. M. Victoravich. 2013. The effect of evidence strength and internal rewards on intentions to report fraud in the Dodd-Frank regulatory environment. Auditing: A Journal of Practice and Theory 32 (3):87-104.

Brown, A. J., E. Mazurski, and J. Olsen. 2008. The incidence and significance of whistleblowing. In Whistleblowing in the Australian Public Sector: Enhancing the Theory and Practice of Internal Witness Management in Public Sector Organizations, edited by A. J. Brown. Canberra: ANU E Press, 25-52.

Callahan, E. S., and T. M. Dworkin. 1994. Who blows the whistle to the media, and why: Organizational characteristics of media whistleblowers. American Business Law Journal 32 (2):151-184.

Carcello, J. V., D. R. Hermanson, T. L. Neal, and R. A. Riley Jr. 2002. Board characteristics and audit fees. Contemporary Accounting Research 19 (3):365-384.

Carcello, J. V., D. R. Hermanson, and Z. Ye. 2011. Corporate governance research in accounting and auditing: Insights, practice implications, and future research directions. Auditing: A Journal of Practice \& Theory 30 (3):1-31.

Cassematis, P., and R. Wortley. 2013. Prediction of whistleblowing or non-reporting observation: The role of personal and situational factors. Journal of Business Ethics 117 (3):615-634.

Chen, Y. M., R. Moroney, and K. Houghton. 2005. Audit committee composition and the use of an industry specialist audit firm. Accounting \& Finance 45 (2):217-239.

Chiasson, M., H. G. Johnson, and J. R. Byington. 1995. Blowing the whistle: Accountants in industry. CPA Journal 65 (2):24-27.

Cohen, J., G. Krishnamoorthy, and A. Wright. 2010. Corporate governance in the post-Sarbanes-Oxley era: Auditors' experiences. Contemporary Accounting Research 27 (3):751-786.

Cowen, A. P., and J. J. Marcel. 2011. Damaged goods: Board decisions to dismiss reputationally compromised directors. Academy of Management Journal 54 (3):509-527.

Curtis, M. B., and E. Z. Taylor. 2009. Whistleblowing in public accounting: Influence of identity disclosure, situational context, and personal characteristics. Accounting and the Public Interest 9 (1):191-220.

Daniel, T. A. 2003. Tools for building a positive employee relations environment. Employment Relations Today 30 (2):51-64.

Dechow, P. M., R. G. Sloan, and A. P. Sweeney. 1996. Causes and consequences of earnings manipulation: An analysis of firms subject to enforcement actions by the SEC. Contemporary Accounting Research 13 (1):1-36.

Donkin, M., R. Smith, and A. J. Brown. 2008. How do officials report? Internal and external whistleblowing. In Whistleblowing in the Australian Public Sector: Enhancing the theory and practice of internal witness management in public sector organisations edited by A. J. Brown. Canberra: Australian National University E Press

Douhou, S., J. R. Magnus, and A. Van Soest. 2012. Peer reporting and the perception of fairness. De Economist 160 (3):289-310.

Doyle, J., W. Ge, and S. McVay. 2007. Determinants of weaknesses in internal control over financial reporting. Journal of Accounting and Economics 44 (1):193-223.

Dworkin, T. M., and M. S. Baucus. 1998. Internal vs. External whistleblowers: A comparison of whistleblowering processes. Journal of Business Ethics 17 (12):1281-1298.

Dyck, A., A. Morse, and L. Zingales. 2010. Who blows the whistle on corporate fraud? The Journal of Finance 65 (6):2213-2253.

Fich, E. M., and A. Shivdasani. 2007. Financial fraud, director reputation, and shareholder wealth. Journal of Financial Economics 86 (2):306-336.

Fiolleau, K., K. Hoang, K. Jamal, and S. Sunder. 2013. How do regulatory reforms to enhance auditor independence work in practice? Contemporary Accounting Research 30 (3):864-890.

Foddy, M., M. J. Platow, and T. Yamagishi. 2009. Group-based trust in strangers the role of stereotypes and expectations. Psychological Science 20 (4):419-422.

Gao, J., R. Greenberg, and B. Wong. 2015. Whisleblowing intentions of lower-level employees: The effect of reporting channel, bystanders and wrongdoer power status. Journal of Business Ethics 126 (1):85-99.

Gendron, Y., and J. Bédard. 2006. On the constitution of audit committee effectiveness. Accounting, Organizations and Society 31 (3):211-239. 
Goh, B. W. 2009. Audit committees, boards of directors, and remediation of material weaknesses in internal control. Contemporary Accounting Research 26 (2):549-579.

Goodwin-Stewart, J., and P. Kent. 2006. Relation between external audit fees, audit committee characteristics and internal audit. Accounting \& Finance 46 (3):387-404.

Goodwin, J. 2003. The relationship between the audit committee and the internal audit function: Evidence from Australia and New Zealand. International Journal of Auditing 7 (3):263-278.

Goodwin, J., and T. Y. Yeo. 2001. Two factors affecting internal audit independence and objectivity: Evidence from Singapore. International Journal of Auditing 5 (2):107-125.

Hooks, K. L., S. E. Kaplan, and J. J. Schultz. 1994. Enhancing communication to assist in fraud prevention and detection. Auditing 13:86-86.

Hou, W., and G. Moore. 2012. Player and referee roles held jointly: The effect of state ownership on china's regulatory enforcement against fraud. In Entrepreneurship, governance and ethics: Springer, 317-335.

Johnson, C. E., T. L. Sellnow, M. W. Seeger, M. S. Barrett, and K. C. Hasbargen. 2004. Blowing the whistle on Fen-Phen: An exploration of meritcare's reporting of linkages between Fen-Phen and valvular heart disease. Journal of Business Communication 41 (4):350-369.

Jubb, P. B. 1999. Whistleblowing: A restrictive definition and interpretation. Journal of Business Ethics 21 (1):77-94.

Kaplan, S., K. Pany, J. Samuels, and J. Zhang. 2009. An examination of the association between gender and reporting intentions for fraudulent financial reporting. Journal of Business Ethics 87 (1):1530.

Kaplan, S. E., K. R. Pope, and J. A. Samuels. 2011. An examination of the effect of inquiry and auditor type on reporting intentions for fraud. Auditing: A Journal of Practice \& Theory 30 (4):29-49.

Kaplan, S. E., and J. J. Schultz. 2006. The role of internal audit in sensitive communications. Florida: The Institute of Internal Auditors Research Foundation.

Karamanou, I., and N. Vafeas. 2005. The association between corporate boards, audit committees, and management earnings forecasts: An empirical analysis. Journal of Accounting Research 43 (3):453-486.

Keenan, J. P. 2000. Blowing the whistle on less serious forms of fraud: A study of executives and managers. Employee Responsibilities and Rights Journal 12 (4):199-217.

Keune, M. B., and K. M. Johnstone. 2015. Audit committee incentives and the resolution of detected misstatements. Auditing: A Journal of Practice \& Theory 34 (4):109-137.

King, G. 1997. The effects of interpersonal closeness and issue seriousness on blowing the whistle. Journal of Business Communication 34 (4):419-436.

Klapper, L. F., and I. Love. 2004. Corporate governance, investor protection, and performance in emerging markets. Journal of Corporate Finance 10 (5):703-728.

Klein, A. 2002. Audit committee, board of director characteristics, and earnings management. Journal of Accounting and Economics 33 (3):375-400.

Koh, P. S., S. K. Laplante, and Y. H. Tong. 2007. Accountability and value enhancement roles of corporate governance. Accounting \& Finance 47 (2):305-333.

KPMG. 2010. Fraud and misconduct survey 2010: Australia and New Zealand

- 2013. A survey of fraud, bribery and corruption in Australia and New Zealand.

Lee, G., and N. Fargher. 2013. Companies' use of whistle-blowing to detect fraud: An examination of corporate whistle-blowing policies. Journal of Business Ethics 114 (2):283-295.

Lee, J. Y., S. G. Heilmann, and J. P. Near. 2004. Blowing the whistle on sexual harassment: Test of a model of predictors and outcomes. Human Relations 57 (3):297-322.

Lewis, D., and M. Spencer. 2001. Whistleblowing and human resource management. In Whistleblowing at work, edited by D. Lewis. London: The Athlone Press, 57-69.

Li, J., M. Mangena, and R. Pike. 2012. The effect of audit committee characteristics on intellectual capital disclosure. The British Accounting Review 44 (2):98-110.

McAllister, D. J. 1995. Affect-and cognition-based trust as foundations for interpersonal cooperation in organizations. Academy of Management Journal 38 (1):24-59.

Méndez, C. F., and R. A. García. 2007. The effects of ownership structure and board composition on the audit committee meeting frequency: Spanish evidence. Corporate Governance: An International Review 15 (5):909-922. 
Mesmer-Magnus, J., and C. Viswesvaran. 2005. Whistleblowing in organizations: An examination of correlates of whistleblowing intentions, actions, and retaliation. Journal of Business Ethics 62 (3):277-297.

Miceli, M. P., and J. P. Near. 1984. The relationships among beliefs, organizational position, and whistle-blowing status: A discriminant analysis. The Academy of Management Journal 27 (4):687-705.

Miceli, M. P., and J. P. Near. 1985. Characteristics of organizational climate and perceived wrongdoing associated with whistleblowing decisions. Personnel Psychology 38 (3):525-544.

Miceli, M. P., and J. P. Near. 1994. Relationships among value congruence, perceived victimization, and retaliation against whistle-blowers. Journal of Management 20 (4):773-794.

Miceli, M. P., and J. P. Near. 2005. Standing up or standing by: What predicts blowing the whistle on organizational wrongdoing? In Research in personnel and human resources management, edited by J. J. Martocchio. Greenwich, CT: Elsevier Press.

Miceli, M. P., J. P. Near, and T. M. Dworkin. 2008. Whistle-blowing in organizations. edited by A. P. Brief and J. P. Walsh. New York, NY: Routledge

Miceli, M. P., J. P. Near, and T. M. Dworkin. 2009. A word to the wise: How managers and policymakers can encourage employees to report wrongdoing. Journal of Business Ethics 86 (3):379396.

Miceli, M. P., M. Rehg, J. P. Near, and K. C. Ryan. 1999. Can laws protect whistle-blowers? Results of a naturally occuring field experiment. Work and Occupations 26 (1):129-151.

Miller, G. S. 2006. The press as a watchdog for accounting fraud. Journal of Accounting Research 44 (5):1001-1033.

Near, J. P., M. S. Baucus, and M. P. Miceli. 1993. The relationship between values and practice. Administration \& Society 25 (2):204-226.

Near, J. P., and T. C. Jensen. 1983. The whistleblowing process: Retaliation and perceived effectiveness. Work and Occupations 10 (1):3-28.

Near, J. P., and M. P. Miceli. 1985. Organizational dissidence: The case of whistle-blowing. Journal of Business Ethics 4 (1):1-16.

Near, J. P., and M. P. Miceli. 2008. Wrongdoing, whistle-blowing, and retaliation in the U.S. Government. Review of Public Personnel Administration 28 (3):263-281.

Osma, B. G., and E. Guillamón-Saorín. 2011. Corporate governance and impression management in annual results press releases. Accounting, Organizations and Society 36 (4):187-208.

Park, H., J. Blenkinsopp, and M. Park. 2014. The influence of an observer's value orientation and personality type on attitudes toward whistleblowing. Journal of Business Ethics 120 (1):121129.

Park, H., M. T. Rehg, and D. Lee. 2005. The influence of confucian ethics and collectivism on whistleblowing intentions: A study of South Korean public employees. Journal of Business Ethics 58 (4):387-403.

Parmerlee, M. A., J. P. Near, and T. C. Jensen. 1982. Correlates of whistle-blowers' perceptions of organizational retaliation. Administrative Science Quarterly 27:17-34.

Pittroff, E. 2014. Whistle-blowing systems and legitimacy theory: A study of the motivation to implement whistle-blowing systems in German organizations. Journal of Business Ethics 124 (3):399-412.

PwC. 2011. How can audit committee members add value?: Available at: http://www.pwc.com.au/assurance/assets/audit-committee-guide/ac-guide-booklet-dec11.pdf.

Raghunandan, K., and D. V. Rama. 2007. Determinants of audit committee diligence. Accounting Horizons 21 (3):265-279.

Raghunandan, K., D. V. Rama, and W. J. Read. 2001. Audit committee composition, 'gray directors', and interaction with internal auditing. Accounting Horizons 15 (2):105-118.

Read, W. J., and D. Rama. 2003. Whistle-blowing to internal auditors. Managerial Auditing Journal 18 (5):354-362.

Rehg, M. T., M. P. Miceli, J. P. Near, and J. R. Van Scotter. 2008. Antecedents and outcomes of retaliation against whistleblowers: Gender differences and power relationships. Organization Science 19 (2):221-240. 
Rothschild, J., and T. D. Miethe. 1999. Whistle-blower disclosures and management retaliation: The battle to control information about organization corruption. Work and Occupations 26 (1):107128.

Schultz, J. J., D. A. Johnson, D. Morris, and S. Dyrnes. 1993. An investigation of the reporting of questionable acts in an international setting. Journal of Accounting Research 31 (Supplement):75-103.

Seifert, D. L., J. T. Sweeney, J. Joireman, and J. M. Thornton. 2010. The influence of organizational justice on accountant whistleblowing. Accounting, Organizations and Society 35 (7):707-717.

Sharma, V. D. 2004. Board of director characteristics, institutional ownership, and fraud: Evidence from Australia. Auditing: A Journal of Practice \& Theory 23 (2):105-117.

Skivenes, M., and S. C. Trygstad. 2010. When whistle-blowing works: The Norwegian case. Human Relations 63 (7):1071-1097.

Smith, R. G. 2008. Coordinating individual and organisational responses to fraud. Crime, Law and Social Change 49 (5):379-396.

Soni, F., W. Maroun, and N. Padia. 2015. Perceptions of justice as a catalyst for whistle-blowing by trainee auditors in South Africa. Meditari Accountancy Research 23 (1):118-140.

Spira, L. 1999. Independence in corporate governance: The audit committee role. Business Ethics: A European Review 8 (4):262-273.

Srinivasan, S. 2005. Consequences of financial reporting failure for outside directors: Evidence from accounting restatements and audit committee members. Journal of Accounting Research 43 (2):291-334.

Stikeleather, B. R. 2016. When do employers benefit from offering workers a financial reward for reporting internal misconduct? Accounting, Organizations and Society 52:1-14.

Tepalagul, N., and L. Lin. 2015. Auditor independence and audit quality a literature review. Journal of Accounting, Auditing \& Finance 30 (1):101-121.

Turley, S., and M. Zaman. 2007. Audit committee effectiveness: Informal processes and behavioural effects. Accounting, Auditing \& Accountability Journal 20 (5):765-788.

Uzun, H., S. H. Szewczyk, and R. Varma. 2004. Board composition and corporate fraud. Financial Analysts Journal 60 (3):33-43.

Van den Berghe, L. A., and A. Levrau. 2004. Evaluating boards of directors: What constitutes a good corporate board? Corporate Governance: An International Review 12 (4):461-478.

Warr, M. 1989. What is the perceived seriousness of crimes? Criminology 27 (4):795-822.

Waytz, A., J. Dungan, and L. Young. 2013. The whistleblower's dilemma and the fairness-loyalty tradeoff. Journal of Experimental Social Psychology 49 (6):1027-1033.

White, H. 1980. A heteroskedasticity-consistent covariance matrix estimator and a direct test for heteroskedasticity. Econometrica: Journal of the Econometric Society 48 (4):817-838.

Williams, M. 2001. In whom we trust: Group membership as an affective context for trust development. Academy of Management Review 26 (3):377-396.

Wolfe, S., M. Worth, S. Dreyfus, and A. Brown. 2014. Whistleblower protection rules in G20 countries: The next action plan.

Xie, B., W. N. Davidson III, and P. J. DaDalt. 2003. Earnings management and corporate governance: The role of the board and the audit committee. Journal of Corporate Finance 9 (3):295-316.

Zhang, J., K. Pany, and P. M. Reckers. 2013. Under which conditions are whistleblowing "best practices" best? Auditing: A Journal of Practice and Theory 32 (3):171-181. 


\begin{tabular}{|c|c|c|c|}
\hline Variable & & Definition & Data source \\
\hline acind & $=$ & $\begin{array}{l}\text { percentage of audit committee members that are } \\
\text { independent, the year prior to the financial } \\
\text { allegation }\end{array}$ & $\begin{array}{l}\text { Annual reports from the } \\
\text { Connect } 4 \text { database }\end{array}$ \\
\hline acexp & $=$ & $\begin{array}{l}\text { percentage of audit committee members that have } \\
\text { professional accounting or finance qualifications, } \\
\text { the year prior to the financial allegation }\end{array}$ & $\begin{array}{l}\text { Annual reports from the } \\
\text { Connect } 4 \text { database }\end{array}$ \\
\hline acmeet & $=$ & $\begin{array}{l}\text { number of audit committee meetings, the year prior } \\
\text { to the financial allegation }\end{array}$ & $\begin{array}{l}\text { Annual reports from the } \\
\text { Connect } 4 \text { database }\end{array}$ \\
\hline$a c$ & $=$ & $\begin{array}{l}\text { composite measure of audit quality, derived by } \\
\text { factor analysis of acind, acexp, and acmeet }\end{array}$ & \\
\hline size & $=$ & $\begin{array}{l}\text { logarithm of total assets in dollars, for the year } \\
\text { before the financial allegation }\end{array}$ & Morningstar's DatAnalysis \\
\hline growth & $=$ & $\begin{array}{l}\text { average change in revenue over the past three years } \\
\text { prior to the financial allegation }\end{array}$ & Morningstar's DatAnalysis \\
\hline complex & $=$ & $\begin{array}{l}\text { average of industry and geographical complexity } \\
\text { where industry complexity is calculated as one } \\
\text { minus the industry segment-sales-based Herfindahl } \\
\text { index; and geographical complexity is calculated as } \\
\text { one minus the geographical segment-sales-based } \\
\text { Herfindahl index }\end{array}$ & $\begin{array}{l}\text { Morningstar's DatAnalysis } \\
\text { and annual reports from the } \\
\text { Connect } 4 \text { database }\end{array}$ \\
\hline pastperf & $=$ & $\begin{array}{l}\text { market-adjusted buy-and-hold returns over the past } \\
\text { one year prior to the financial allegation }\end{array}$ & Morningstar's DatAnalysis \\
\hline inddir & $=$ & $\begin{array}{l}\text { proportion of the board of directors that are } \\
\text { independent directors }\end{array}$ & $\begin{array}{l}\text { Annual reports from the } \\
\text { Connect } 4 \text { database }\end{array}$ \\
\hline brdmeet & $=$ & $\begin{array}{l}\text { number of board meetings, the year prior to the } \\
\text { financial allegation }\end{array}$ & $\begin{array}{l}\text { Annual reports from the } \\
\text { Connect } 4 \text { database }\end{array}$ \\
\hline frdamt & $=$ & $\begin{array}{l}\text { logarithm of fraud amount in dollars as reported in } \\
\text { the press }\end{array}$ & $\begin{array}{l}\text { Press articles obtained from } \\
\text { a Factiva search }\end{array}$ \\
\hline wbsys & $=$ & $\begin{array}{l}\text { factor score of hotline, anon, wbo and protect where } \\
\text { hotline = " } 1 \text { " if the firm provides an internal } \\
\text { reporting hotline channel as reported in the annual } \\
\text { report of the year prior to the financial allegation, } \\
\text { and " } 0 \text { " otherwise; anon = " } 1 \text { " if provision of an } \\
\text { anonymous reporting system is disclosed in the } \\
\text { annual report of the year prior to the financial } \\
\text { allegation, and " } 0 \text { " otherwise; } w b o=\text { " } 1 \text { " if the firm } \\
\text { provides a designated whistle-blowing officer as } \\
\text { reported in the annual report of the year prior to the } \\
\text { financial allegation, and " } 0 \text { " otherwise; } \\
\text { protect = " } 1 \text { " if protection for whistle-blowing is } \\
\text { disclosed in the annual report of the year prior to the } \\
\text { financial allegation }\end{array}$ & $\begin{array}{l}\text { Annual reports from the } \\
\text { Connect } 4 \text { database }\end{array}$ \\
\hline extwb & $=$ & $\begin{array}{l}\text { indicator variable coded “1” if the alleged fraud was } \\
\text { referenced in the press to have been uncovered by } \\
\text { external whistle-blowing, and “0” when referenced } \\
\text { to have been uncovered by internal reporting }\end{array}$ & $\begin{array}{l}\text { Press articles obtained from } \\
\text { a Factiva search }\end{array}$ \\
\hline retaliated & $=$ & $\begin{array}{l}\text { indicator variable coded " } 1 \text { " if the whistle-blower } \\
\text { was referenced in the press to have been retaliated } \\
\text { against for whistle-blowing, and " } 0 \text { " otherwise }\end{array}$ & $\begin{array}{l}\text { Press articles obtained from } \\
\text { a Factiva search }\end{array}$ \\
\hline
\end{tabular}


Figure 1: Types of whistle-blowing events captured in the sample

Whistle-blowing events Actions taken following the whistle-blowing report

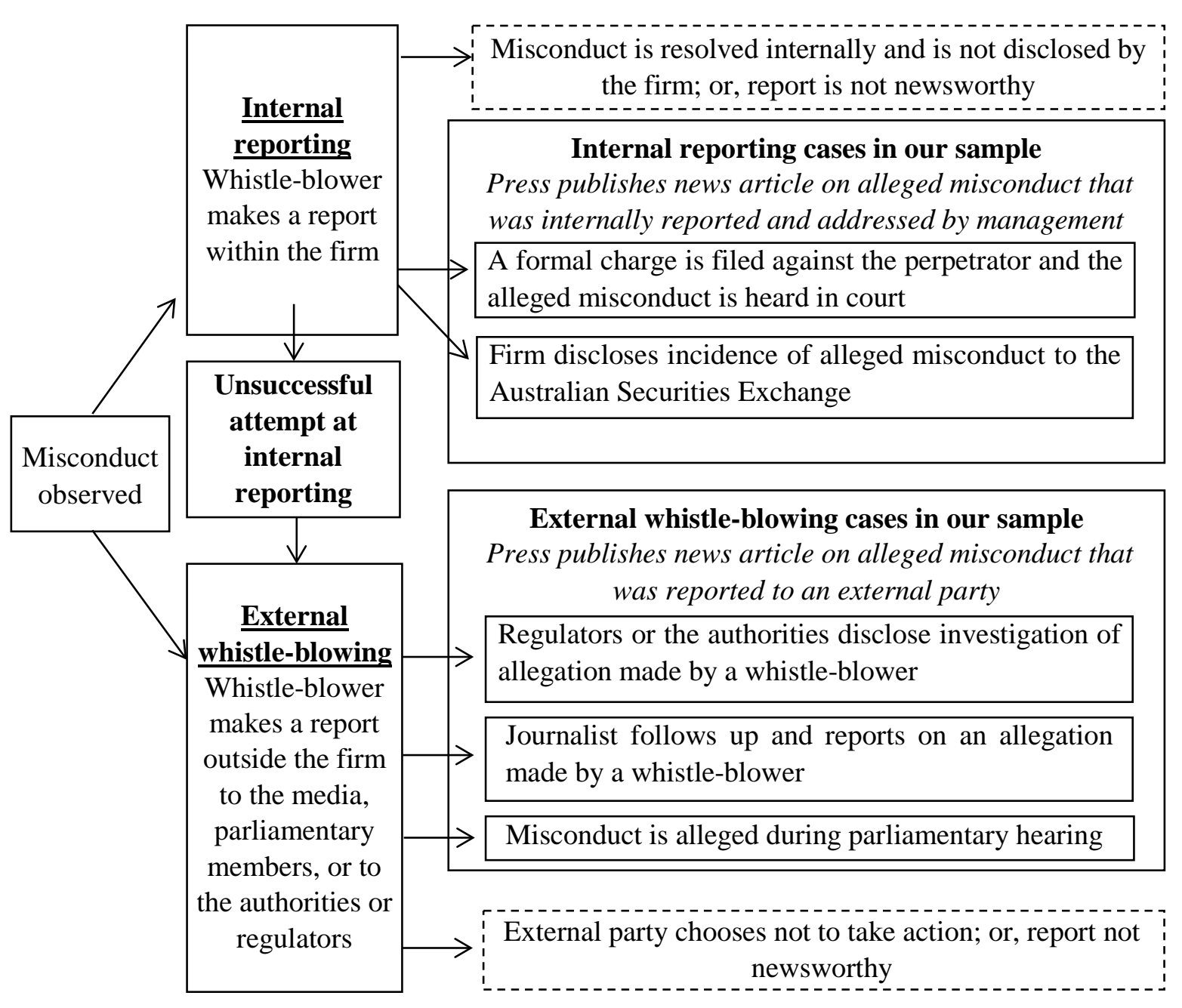

Note 1: Dashed-line boxes indicate that these allegations are not observable from press reports.

Note 2: The cases classified as external whistle-blowing involve the whistle-blower reporting an alleged financial misconduct to an external party. External whistle-blowing involves either an allegation that was preceded by an unsuccessful attempt at internal whistle-blowing, or the whistle-blower directly disclosing an allegation outside the organization. The cases classified as internal reporting, while publicly observable, do not involve the whistle-blower reporting an alleged financial misconduct to an external party. 


\section{Table 1: Sample selection}

\begin{tabular}{lc}
\hline Incidence of financial allegations reported in the press (1992-2013) & 554 \\
Less: Multiple financial allegations reported in a firm in the same year & 50 \\
Less: Unavailable financial data from Morningstar and the Connect 4 database & 32 \\
Less: Allegations not attributed to external whistle-blowing or internal reporting & 154 \\
\hline Sample size & 318 \\
\hline
\end{tabular}

This table describes the sample selection procedure for this study. The initial 554 cases of alleged financial misconduct were gathered from press reports by conducting searches on Factiva using terms such as "fraud”, “financial fraud”, “theft”, “misappropriation”, “corruption”, “defraud”, "bribery”, "kickbacks”, “rort”, “insider trading”, “money laundering”, “corporate fraud”, and "fraudulent reporting”. The final sample size consists of 318 firm-year observations of allegations of financial misconduct that were reported in the press. 
Table 2: Financial allegations reported in the press by type of financial misconduct

\begin{tabular}{|c|c|c|c|c|c|c|c|c|}
\hline \multirow[b]{2}{*}{ Type of allegation } & \multicolumn{2}{|c|}{ Full sample } & \multicolumn{2}{|c|}{$\begin{array}{c}\text { External } \\
\text { whistle-blowing }\end{array}$} & \multicolumn{2}{|c|}{ Internal reporting } & \multicolumn{2}{|c|}{ Differences in proportion } \\
\hline & No. & $\%$ & No. & $\%$ & No. & $\%$ & z-score & $p$-value \\
\hline Bribery & 25 & 8 & 17 & 18 & 8 & 4 & $4.173 * *$ & 0.000 \\
\hline Fraudulent financial reporting & 27 & 8 & 11 & 11 & 16 & 7 & 1.196 & 0.232 \\
\hline Improper disclosure & 12 & 4 & 8 & 8 & 4 & 2 & $2.567 *$ & 0.010 \\
\hline Insider trading & 7 & 2 & 3 & 3 & 4 & 2 & 0.547 & 0.584 \\
\hline Market manipulation & 4 & 1 & 1 & 1 & 3 & 1 & 0.000 & 1.000 \\
\hline Misappropriation of funds or assets & 175 & 55 & 5 & 5 & 170 & 77 & $-11.884^{* *}$ & 0.000 \\
\hline Misuse of funds & 33 & 10 & 22 & 23 & 11 & 5 & $4.823 * *$ & 0.000 \\
\hline Money laundering & 2 & 1 & 0 & 0 & 2 & 1 & -0.988 & 0.323 \\
\hline Price-fixing & 31 & 10 & 30 & 31 & 1 & 0 & $8.699 * *$ & 0.000 \\
\hline Tax evasion & 2 & 1 & 0 & 0 & 2 & 1 & -0.988 & 0.323 \\
\hline Total & 318 & & 97 & & 221 & & & \\
\hline
\end{tabular}

$* * *, * *, *$ represent significance at the $0.01,0.05$, and 0.1 levels (two-tailed), respectively.

This table reports the type of financial allegation, as reported in the press. The coding of the type of alleged financial misconduct is described as follows. Bribery: an allegation was attributed as bribery if the perpetrator(s) engaged in taking or receiving monetary or non-monetary bribes. Fraudulent financial reporting: an allegation was attributed as fraudulent financial reporting if the perpetrator(s) engaged in the manipulation of financial accounts with the intent to mislead stakeholders about the firm's economic performance. Improper disclosure: an allegation was attributed as improper disclosure if the perpetrator(s) fraudulently engaged in making false or deceptive statements with the intent to defraud. Insider trading: an allegation was attributed to insider trading if the perpetrator(s) fraudulently engaged in trading of shares, or had procured someone to trade on shares on their behalf, based on inside information. Market manipulation: an allegation was attributed as market manipulation if the perpetrator(s) fraudulently engaged in the trading of shares to create artificial, false, or misleading appearances of the firm's share price. Misappropriation of funds or assets: an allegation was attributed as misappropriation of funds or assets if the perpetrator(s) stole, siphoned off, or embezzled money or other assets. Misuse of funds: an allegation was attributed to the misuse of funds if the perpetrator(s) used a firm's funds other than for their intended purposes. Money laundering: an allegation was attributed as money laundering if the perpetrator(s) engaged in money laundering. Price-fixing: an allegation was attributed to price-fixing if the perpetrator(s) entered agreements with other firms to fix, control, or maintain prices. Tax evasion: an allegation was attributed as tax evasion if the perpetrator(s) engaged in misconduct to evade or reduce their tax burden. 
Table 3: Descriptive statistics

\begin{tabular}{|c|c|c|c|c|c|c|c|c|c|c|c|}
\hline & & & & & & $\begin{array}{c}\text { extwb } \\
=1 \\
n=97\end{array}$ & $\begin{array}{c}\text { extwb } \\
=0 \\
n=221\end{array}$ & $t$ & $\begin{array}{c}\text { retaliated } \\
\quad=1 \\
n=38\end{array}$ & $\begin{array}{l}\text { retaliated } \\
\quad=0 \\
n=280\end{array}$ & $t$ \\
\hline Continuous variables & Mean & Q1 & Median & Q3 & Std. dev. & \multicolumn{2}{|c|}{ Mean } & \multicolumn{4}{|c|}{ Mean } \\
\hline acind & 0.846 & 0.750 & 1.00 & 1 & 0.270 & 0.743 & 0.890 & $4.621 * * *$ & 0.729 & 0.862 & $2.875 * * *$ \\
\hline acexp & 0.379 & 0.250 & 0.33 & 0.5 & 0.269 & 0.316 & 0.407 & $2.810 * * *$ & 0.360 & 0.382 & 0.469 \\
\hline acmeet & 4.987 & 3.000 & 5.00 & 7 & 2.731 & 4.485 & 5.208 & $2.189 * *$ & 4.342 & 5.075 & 1.556 \\
\hline Total assets (in AUD\$mil) & 79,700 & 729 & 6,330 & 48,700 & 164,000 & & & & & & \\
\hline size $(\log )$ & 22.376 & 20.407 & 22.57 & 24.608 & 2.989 & 22.127 & 22.486 & 0.985 & 22.452 & 22.366 & -0.167 \\
\hline Fraud amount (in AUD\$’00) & 35,700 & 115.5 & 1,235 & 9,300 & 158,000 & & & & & & \\
\hline frdamt (log) & 13.829 & 11.657 & 14.03 & 16.045 & 3.149 & 15.796 & 12.966 & -8.091 & 15.922 & 13.545 & $-4.496 * * *$ \\
\hline growth & 0.111 & 0.023 & 0.09 & 0.1846 & 0.297 & 0.077 & 0.125 & 1.327 & 0.031 & 0.121 & $1.775^{*}$ \\
\hline complex & 0.339 & 0.212 & 0.33 & 0.503 & 0.208 & 0.385 & 0.318 & $-2.660 * * *$ & 0.379 & 0.333 & -1.261 \\
\hline pastperf & 0.176 & -0.166 & 0.04 & 0.233 & 1.618 & 0.466 & 0.048 & $-2.131 * *$ & 0.839 & 0.085 & $-2.71 * * *$ \\
\hline inddir & 0.774 & 0.714 & 0.80 & 0.875 & 0.141 & 0.747 & 0.786 & $2.332 * *$ & 0.747 & 0.778 & 1.290 \\
\hline brdmeet & 12.022 & 10.000 & 11.00 & 14 & 4.390 & 12.113 & 11.982 & -0.246 & 13.368 & 11.839 & $-2.025 *$ \\
\hline Dichotomous variables & “1” & $\%$ & “0” & $\%$ & & & & & & & \\
\hline extwb & 97 & 30.50 & 221 & 69.50 & & & & & 0.737 & 0.246 & $-6.545^{* * *}$ \\
\hline $\begin{array}{l}\text { retaliated } \\
\mathrm{n}=318\end{array}$ & 38 & 11.95 & 280 & 88.05 & & 0.289 & 0.045 & $-6.545 * * *$ & & & \\
\hline
\end{tabular}

$* * *, * *, *$ represent significance at the $0.01,0.05$, and 0.1 levels (two-tailed), respectively.

This table provides descriptive statistics of the variables in the model. See appendix for variable definitions. 
Table 4: Factors associated with the likelihood that financial misconduct is uncovered by external whistle-blowing in comparison to internal reporting

\begin{tabular}{lllll}
\hline & \multicolumn{2}{c}{$\begin{array}{c}\text { Composite audit committee } \\
\text { quality measure } \\
(1)\end{array}$} & \multicolumn{2}{c}{$\begin{array}{c}\text { Individual audit committee quality } \\
\text { measures } \\
(2)\end{array}$} \\
\hline & coefficient & z & coefficient & z \\
\hline Variables of interest & & & & \\
ac & $-1.289^{* * *}$ & 4.14 & $-2.295^{* * *}$ & -2.93 \\
acind & & & -0.292 & -0.39 \\
acexp & & & $-0.172^{* *}$ & -2.26 \\
acmeet & & & & \\
Control variables & & & $0.337^{* * *}$ & 3.16 \\
size & $0.318^{* * *}$ & 3.23 & $2.444^{* *}$ & 2.19 \\
complex & $2.372^{* *}$ & 2.05 & -0.277 & -0.41 \\
growth & -0.246 & -0.38 & $0.659^{* *}$ & 2.50 \\
pastperf & $0.667^{* * *}$ & 2.59 & $-2.208^{*}$ & -1.90 \\
inddir & $-2.224^{*}$ & -1.88 & 0.012 & 0.30 \\
brdmeet & 0.010 & 0.24 & $0.419^{* * *}$ & 5.68 \\
frdamt & $0.421^{* * *}$ & 5.60 & $-11.621^{* * *}$ & -4.53 \\
Constant & $-14.114^{* * *}$ & -4.83 & Yes & \\
Industry dummies & Yes & & 318 & \\
n & 318 & & -130.866 & \\
Log pseudolikelihood & -131.306 & & 0.331 & \\
Pseudo R-squared & 0.329 & & & \\
\hline
\end{tabular}

This table reports the results of a logit regression that examines the effect of audit committee quality on the likelihood of external versus internal whistle-blowing (extwb). Standard errors are clustered by firm. $* * *, * *, *$ represent significance at the $0.01,0.05$, and 0.1 levels (two-tailed), respectively. See appendix for variable definitions. 
Table 5: Factors associated with the likelihood of whistle-blowing retaliation

\begin{tabular}{lllll}
\hline & \multicolumn{2}{c}{$\begin{array}{c}\text { Composite audit committee quality } \\
\text { measure } \\
(1)\end{array}$} & \multicolumn{2}{c}{$\begin{array}{c}\text { Individual audit committee quality } \\
\text { measures } \\
\text { (2) }\end{array}$} \\
\hline & coefficient & \multicolumn{1}{c}{ coefficient } & Z \\
\hline Variables of interest & & & & \\
ac & $-0.795^{* *}$ & -2.19 & $-1.605^{* *}$ & -2.03 \\
acind & & & 0.837 & 1.07 \\
acexp & & & $-0.215^{*}$ & -1.84 \\
acmeet & & & & \\
Control variables & & & $0.211^{*}$ & 1.76 \\
size & 0.130 & 1.10 & $2.423^{*}$ & 1.93 \\
complex & $2.068^{*}$ & 1.67 & -0.634 & -0.87 \\
growth & -0.534 & -0.75 & 0.479 & 1.19 \\
pastperf & 0.481 & 1.22 & -0.604 & -0.41 \\
inddir & -0.304 & -0.20 & 0.062 & 1.48 \\
brdmeet & 0.051 & 1.11 & $0.275^{* * *}$ & 4.07 \\
frdamt & $0.279^{* * *}$ & 4.01 & $-15.904^{* * *}$ & -2.69 \\
Constant & $-16.443^{* * *}$ & -2.75 & Yes & \\
Industry dummies & Yes & & 318 & \\
n & 318 & & -88.247 & \\
Log pseudolikelihood & -89.966 & & 0.242 & \\
Pseudo R-squared & 0.227 & & & \\
\hline
\end{tabular}

This table reports the results of a logit regression that examines the effect of audit committee quality on the likelihood of whistle-blowing retaliation (retaliated). Standard errors are clustered by firm. ***, **, * represent significance at the 0.01, 0.05, and 0.1 levels (two-tailed), respectively. See appendix for variable definitions. 
Table 6: Strength of whistle-blowing system

\begin{tabular}{lllll}
\hline & \multicolumn{2}{c}{$\begin{array}{c}\text { Composite audit committee } \\
\text { quality measure } \\
\text { (1) }\end{array}$} & \multicolumn{2}{c}{$\begin{array}{c}\text { Individual audit committee quality } \\
\text { measures } \\
\text { (2) }\end{array}$} \\
\hline Variables of interest & coefficient & $t$ & coefficient & $t$ \\
ac & & & & \\
acind & $0.392^{* *}$ & 2.00 & $0.650^{* *}$ & 2.04 \\
acexp & & & $1.003^{* *}$ & 2.26 \\
acmeet & & & -0.030 & -0.35 \\
Control variables & & & & \\
size & $0.194^{* * *}$ & 3.21 & $0.230^{* * *}$ & 3.21 \\
complex & $0.967^{*}$ & 1.68 & $1.090^{*}$ & 1.84 \\
growth & $-0.357^{*}$ & -1.91 & $-0.465^{* *}$ & -2.44 \\
pastperf & -0.033 & -1.54 & -0.032 & -1.45 \\
inddir & 0.090 & 0.12 & 0.008 & 0.01 \\
brdmeet & -0.018 & -0.77 & -0.015 & -0.64 \\
Constant & $-3.253^{* *}$ & -2.29 & $-4.791^{* * *}$ & -3.46 \\
Industry dummies & Yes & & Yes & \\
n & 318 & & 318 & \\
F & 9.13 & & 8.18 & \\
Adjusted R-squared & 0.297 & & 0.317 & \\
\hline & & & & \\
\hline
\end{tabular}

This table reports the results that examine the effect of audit committee quality on the strength of the whistle-blowing system (wbsys). Standard errors are clustered by firm. ***, **, * represent significance at the $0.01,0.05$, and 0.1 levels (two-tailed), respectively. See appendix for variable definitions. 
Table 7: Additional analyses

Panel A: The relation of audit committee quality, strength of the internal whistle-blowing system and retaliation on whistle-blowing

\begin{tabular}{|c|c|c|c|c|c|c|}
\hline & \multicolumn{2}{|c|}{$\begin{array}{l}\text { Strength of whistle- } \\
\text { blowing system } \\
\text { (wbsys) } \\
\text { (1) }\end{array}$} & \multicolumn{2}{|c|}{$\begin{array}{l}\text { Whistle-blowing } \\
\text { retaliation } \\
\text { (retaliate) } \\
\text { (2) }\end{array}$} & \multicolumn{2}{|c|}{$\begin{array}{l}\text { External versus internal } \\
\text { whistle-blowing } \\
(\text { extwb) } \\
\text { (3) }\end{array}$} \\
\hline & coefficient & Z & coefficient & Z & coefficient & Z \\
\hline$a c$ & $0.114^{*}$ & 1.79 & $-0.077 * * *$ & -3.21 & $-0.151 * * *$ & -5.09 \\
\hline wbsys & & & -0.023 & -1.16 & $-0.045^{*}$ & -1.74 \\
\hline retaliated & & & & & $0.279 * * *$ & 4.12 \\
\hline Control variables & Yes & & Yes & & Yes & \\
\hline $\begin{array}{l}\text { Industry } \\
\text { dummies }\end{array}$ & Yes & & Yes & & Yes & \\
\hline $\mathrm{n}$ & 318 & & 318 & & 318 & \\
\hline R-squared & 0.246 & & 0.13 & & 0.490 & \\
\hline
\end{tabular}

This table reports the results of a path analysis that examines the relation between audit committee quality ( $a c$ ), strength of the whistle-blowing system (wbsys), whistle-blowing retaliation (retaliated), and external versus internal whistle-blowing $(e x t w b) . * * *, * *, *$ represent significance at the $0.01,0.05$, and 0.1 levels (two-tailed), respectively. See appendix for variable definitions.

Panel B: Employee versus non-employee whistle-blowing

\begin{tabular}{|c|c|c|c|c|c|c|c|c|}
\hline & \multicolumn{4}{|c|}{ extwb } & \multicolumn{4}{|c|}{ retaliated } \\
\hline & \multicolumn{2}{|c|}{$\begin{array}{c}\text { Employee } \\
\text { whistle-blowing } \\
(1) \\
\end{array}$} & \multicolumn{2}{|c|}{$\begin{array}{c}\text { Non-employee } \\
\text { whistle-blowing } \\
(2)\end{array}$} & \multicolumn{2}{|c|}{$\begin{array}{l}\text { Employee whistle- } \\
\text { blowing } \\
\text { (3) }\end{array}$} & \multicolumn{2}{|c|}{$\begin{array}{c}\text { Non-employee } \\
\text { whistle-blowing } \\
(4) \\
\end{array}$} \\
\hline & coeff. & $z$ & coeff. & $z$ & coeff. & $z$ & coeff. & $z$ \\
\hline \multicolumn{9}{|l|}{ Variable of interest } \\
\hline$a c$ & $-1.259 * *$ & -2.52 & -0.569 & -1.06 & $-0.976 * *$ & -2.19 & -0.988 & -1.58 \\
\hline Control variables & Yes & & Yes & & Yes & & Yes & \\
\hline $\begin{array}{l}\text { Industry } \\
\text { dummies }\end{array}$ & Yes & & Yes & & Yes & & Yes & \\
\hline $\mathrm{n}$ & 227 & & 91 & & 227 & & 91 & \\
\hline $\begin{array}{l}\text { Log } \\
\text { pseudolikelihood }\end{array}$ & -52.300 & & $\begin{array}{l}-37.72 \\
5\end{array}$ & & -54.695 & & -22.665 & \\
\hline $\begin{array}{l}\text { Pseudo R- } \\
\text { squared }\end{array}$ & 0.427 & & 0.274 & & 0.308 & & 0.223 & \\
\hline
\end{tabular}

Columns (1) and (2) report logit regression results of the likelihood of external versus internal whistleblowing (extwb) by employees and non-employees. Columns (3) and (4) report logit regression results of the likelihood of retaliation (retaliated) by employees and non-employees. Standard errors are clustered by firm. ${ }^{* * *}, * *, *$ represent significance at the $0.01,0.05$, and 0.1 levels (two-tailed), respectively. 
Panel C: Overall corporate governance and whistle-blowing

\begin{tabular}{lllll}
\hline Dependent variable $=$ & \multicolumn{2}{c}{ extwb } & \multicolumn{2}{c}{ retaliated } \\
& & $(1)$ & & (2) \\
\hline & coefficient & $z$ & coefficient & z \\
\hline corpgov & $-0.476^{*}$ & -1.92 & $-0.744^{* *}$ & -2.03 \\
Variables of interest & & & & \\
$a c$ & $-1.128^{* * *}$ & -3.53 & -0.150 & -0.52 \\
Control variables & Yes & & Yes & \\
Industry dummies & Yes & & Yes & \\
$\mathrm{n}$ & 318 & & 318 & \\
Log pseudolikelihood & -129.546 & & -89.833 & \\
Pseudo R-squared & 0.338 & & 0.217 & \\
\hline
\end{tabular}

This table reports logit regression results with the inclusion of overall corporate governance (corpgov). Standard errors are clustered by firm. ***, **, * represent significance at the $0.01,0.05$, and 0.1 levels (two-tailed), respectively.

Panel D: CEO duality and whistle-blowing

\begin{tabular}{lllll}
\hline Dependent variable $=$ & \multicolumn{2}{c}{ extwb } & \multicolumn{2}{c}{ retaliated } \\
& & $(1)$ & & \\
\hline & coefficient & $z$ & coefficient & z \\
\hline ceoduality & 1.332 & 1.30 & 0.976 & 0.94 \\
Variables of interest & & & & \\
ac & $-1.310^{* * *}$ & -4.17 & $-0.793^{* *}$ & -2.18 \\
Control variables & Yes & & Yes & \\
Industry dummies & Yes & & Yes & \\
$\mathrm{n}$ & 318 & & 318 & \\
Log pseudolikelihood & -130.729 & & -89.730 & \\
Pseudo R-squared & 0.332 & & 0.218 & \\
\hline
\end{tabular}

This table reports logit regression results with the inclusion of CEO duality (ceoduality). Standard errors are clustered by firm. $* * *, * *, *$ represent significance at the $0.01,0.05$, and 0.1 levels (two-tailed), respectively.

Panel E: Monitoring by shareholders and whistle-blowing

\begin{tabular}{lllll}
\hline Dependent variable $=$ & \multicolumn{2}{c}{ extwb } & \multicolumn{2}{c}{$\begin{array}{c}\text { retaliated } \\
(2)\end{array}$} \\
\hline & coefficient & $\mathrm{z}$ & coefficient & $\mathrm{Z}$ \\
\hline sharehold & -0.845 & -0.75 & -0.896 & -0.71 \\
Variable of interest & & & & \\
$a c$ & $-1.289 * * *$ & -4.11 & $-0.827^{* *}$ & -2.23 \\
Control variables & Yes & & Yes & \\
Industry dummies & Yes & & Yes & \\
$\mathrm{n}$ & 317 & & 317 & \\
Log pseudolikelihood & -129.569 & & -87.615 & \\
Pseudo R-squared & 0.334 & & 0.222 & \\
\hline
\end{tabular}

This table reports logit regression results with the inclusion of the percentage shareholdings held by top 20 shareholders (sharehold). Standard errors are clustered by firm. ***, **, * represent significance at the $0.01,0.05$, and 0.1 levels (two-tailed), respectively. 
Panel F: Audit quality and whistle-blowing

\begin{tabular}{lllll}
\hline Dependent variable & \multicolumn{2}{c}{ extwb } & \multicolumn{2}{c}{ retaliated } \\
& & $(1)$ & & (2) \\
\hline & coefficient & $\mathrm{z}$ & coefficient & $\mathrm{Z}$ \\
\hline big4 & -0.561 & -1.30 & 0.217 & 0.50 \\
auditfee & -0.247 & -0.87 & -0.339 & -0.81 \\
Variable of interest & & & & \\
ac & $-1.246^{* * *}$ & -4.01 & $-0.825^{* *}$ & -2.17 \\
Control variables & Yes & & Yes & \\
Industry dummies & Yes & & Yes & \\
n & 318 & & 304 & \\
Log pseudolikelihood & -128.481 & & -87.257 & \\
Pseudo R-squared & 0.339 & & 0.225 & \\
\hline
\end{tabular}

This table reports logit regression results of the likelihood of external versus internal whistle-blowing (extwb) with the inclusion of Big 4 auditor (big4) and the natural logarithm of audit fee (auditfee). Standard errors are clustered by firm. $* * *, * *, *$ represent significance at the $0.01,0.05$, and 0.1 levels (two-tailed), respectively. 